\title{
DOSSIÊ
}

\section{Reflexões sobre o discurso midiático brasileiro e a legitimação da punição}

Samuel Rivetti Rocha Balloute ${ }^{1}$

Como citar este artigo: BALLOUTE, Samuel Rivetti Rocha. Reflexões sobre o discurso midiático brasileiro e a legitimação da punição Revista de Ciências do Estado. Belo Horizonte: v. 6, n. 1, e33004. ISSN: 2525-8036.

Resumo: O presente artigo visa refletir sobre a abordagem que a mídia brasileira destina à criminalidade (principalmente urbana), e como ela contribui para a legitimação do atual estado punitivo. A questão criminal é retratada pelos meios de comunicação de massa de tal maneira que produz deformações na realidade e, por consequência, influencia na formação de opiniões pelo público leigo, que confia na informação midiática e muitas vezes absorve sua mensagem. Sua abordagem do problema basicamente tem como padrão o reforço de estereótipos e do ideal punitivo, com ausência de debates sobre pontos de vistas diferentes. Desta forma, a partir da constatação do tempo que os cinco maiores canais de televisão destinam para programas que tratam central ou tangencialmente da questão criminal, refletese sobre o impacto que o ponto de visa midiático causa na sociedade, buscando-se demonstrar a correlação existente entre o recrudescimento da legislação penal, o aumento do encarceramento e o modo como a mídia aborda as notícias criminais. Foi utilizado o procedimento de amostragem (para selecionar e analisar a grade de programação dos canais televisivos), e o de revisão bibliográfica (para situar, investigar e interpretar o problema definido no âmbito Criminologia).

Palavras-chave: Mídia; Direito Penal; Criminalidade urbana; Violência; Televisão.

Recebido em 07.04.2021

Aprovado em 26.06.2021

Publicado em 28.06.2021

\section{INTRODUÇÃO}

O presente artigo aborda como se dá o tratamento midiático sobre a criminalidade sobretudo a urbana - e reflete sobre seu impacto no sistema penal brasileiro. Como criminalidade urbana, entende-se os crimes que ocorrem cotidianamente nas cidades (pequenas ou grandes), principalmente nos espaços públicos, tal como o tráfico de drogas, os crimes patrimoniais, os homicídios (em menor medida), e os sequestros.

\footnotetext{
${ }^{1}$ Graduando em Direito pela Universidade Federal de Minas Gerais (UFMG). Editor-Adjunto da Revista do CAAP. Extensionista no Programa Apenas Humanos: ações interdisciplinares no âmbito da APAC de Santa Luzia, da PUC Minas.
} 
É traçado um panorama crítico, que destaca como os meios midiáticos brasileiros principalmente os representantes dos principais canais de televisão do país - constroem um discurso sobre a criminalidade e o sistema penal que influencia diretamente tanto a concepção da população, quanto a adoção de políticas atinentes a este tema. Desta forma, o efeito é a reafirmação e legitimação do atual status de encarceramento e restrição de direitos que o país vivencia.

As grandes plataformas midiáticas divulgam massivamente determinadas situações de crime, especialmente as que envolvem grupos muito delimitados da sociedade, e adotam um discurso bem específico, que reforça estereótipos e propicia um julgamento popular fora dos órgãos judiciários (onde verdadeiramente existe a atribuição de julgar e de formar culpa). Essa situação é ainda agravada pois se dá sem o direito ao Contraditório - um dos pilares do Estado Democrático de Direito - sendo as únicas vozes autorizadas dentro desse sistema aquelas que reforçam o atual status quo penal.

A hipótese que se constrói é no sentido de que os meios midiáticos brasileiros - em especial os televisivos - são um dos fatores que legitimam o atual sistema penal brasileiro: seletivo, preconceituoso e violento. Isto se reflete em especial no sistema carcerário, cujo perfil dos presos está diretamente relacionado ao perfil dos agentes supostamente infratores que a mídia foca as suas atenções. Consequentemente, há um desvirtuamento do Direito Penal, de modo a criar preconcepções (equivocadas) racistas e seletivas na população, impactando os agentes públicos envolvidos com o sistema penal e, principalmente, o Poder Legislativo.

Assim, o texto busca demonstrar de que modo a mídia brasileira aborda situações de crime em seus telejornais, expondo determinados sujeitos ao rótulo de criminoso a ser perseguido e aniquilado, e elevando-o à condição de inimigo da sociedade. Ademais, busca-se demonstrar a relação entre esse discurso e o agravamento do sistema penal brasileiro, com as frequentes restrições de direitos e leis penais cada vez mais gravosas.

Utilizou-se o procedimento de amostragem para apurar o tempo que os cinco principais canais de televisão do país dedicam a programas que tratam direta ou indiretamente da questão criminal, e selecionou-se como amostra, a título ilustrativo, a programação dos dias 21 a 25 de junho de 2021. Além disso, também foi utilizado o procedimento de revisão bibliográfica, para situar, investigar e analisar o problema, a partir de livros, artigos e pesquisas de acadêmicos, penalistas e criminólogos críticos que tratam da temática.

Dessa forma, buscar-se-á evidenciar as características do discurso midiático no que diz respeito à criminalidade no país, seu modus operandi, dados recentes que revelam como 
sua influência se traduz no perfil da população carcerária nacional, e exemplos de legislações penais editadas por sua pressão, procurando demonstrar de que modo sua atuação enfraquece o Estado de Direito e legitima o atual estado punitivo.

\section{BREVE PANORAMA DA MÍDIA BRASILEIRA}

O rádio e a televisão são os instrumentos midiáticos mais presentes na vida do brasileiro. Porém, a televisão, por veicular imagens, tem um poder de influência ainda maior². Para BORDIEU (1997), “a televisão tem uma espécie de monopólio de fato sobre a formação das cabeças de uma parcela muito importante da população" (p. 23).

Para se ter uma noção do alcance que a televisão possui no Brasil, o Instituto Brasileiro de Geografia e Estatística (IBGE) apurou, em 2018, que cerca de 96,4\% dos domicílios brasileiros possuíam televisão (IBGE, 2018), sendo que a região Norte, a que menos possui domicílios com acesso à televisão, registrava 92,3\% de presença do aparelho. Os dados demonstram o enorme potencial de penetração que este instrumento possui na vida dos habitantes.

Este em tese seria um bom cenário, uma vez que a televisão é um instrumento de difusão de informações, entretenimento e cultura. Porém, no caso latino-americano e, principalmente, brasileiro, essas estatísticas revelam um cenário não tão favorável. Isto se dá pois os meios midiáticos nacionais, especialmente a televisão, são caracterizados pelo oligopólio, o que leva, inexoravelmente, à falta de pluralidade e diversidade nas informações e opiniões veiculadas. Esta concentração também é observada em toda a América Latina, como nos casos da Colômbia, do Chile e do México (BECERRA; MASTRINI, 2017).

A televisão aberta - o instrumento que tem maior poder de influência e de impacto nos lares brasileiros - atualmente se concentra basicamente em cinco grandes conglomerados televisivos: o grupo Globo, a rede Bandeirantes, o Sistema Brasileiro de Televisão (SBT), a rede Record e a RedeTV!. Estes, por meio de suas afiliadas, conseguem alto grau de inserção por todo o país. Este fato é verificado quando se observa que apenas a Rede Globo, em 2015, atingia 99,51\% dos habitantes, e o SBT cobria 87\% do território (MARINONI, 2015, p. 9).

\footnotetext{
${ }^{2}$ BORDIEU (1997) realiza reflexão muito interessante sobre o poder da imagem televisiva na mente do telespectador. De acordo com o autor, "Os perigos políticos inerentes ao uso ordinário da televisão devem-se ao fato de que a imagem tem a particularidade de poder produzir o que os críticos literários chamam o efeito de real, ela pode fazer ver e fazer crer no que faz ver. Esse poder de evocação tem efeitos de mobilização. Ela pode fazer existir ideias ou representações, mas também grupos. As variedades, os incidentes ou os acidentes cotidianos podem estar carregados de implicações políticas, éticas etc. capazes de desencadear sentimentos fortes, frequentemente negativos, como o racismo, a xenofobia, o medo-ódio do estrangeiro, e a simples narração, o fato de relatar, to record, como repórter, implica sempre uma construção social da realidade capaz de exercer efeitos sociais de mobilização (ou de desmobilização)" (p. 28).
} 
Ao se analisar o discurso veiculado por essas redes, um fator de suma importância deve ser salientado: os donos e/ou acionistas dessas grandes redes televisivas possuem atividades em outros setores econômicos - como o agronegócio e o mercado financeiro - não se restringindo à comunicação (BANDEIRA; PASTI, 2018). Isso é relevante pois denota uma clara demarcação de classe sobre quem detém a propriedade desses meios: a classe rica dominante brasileira. Com isso, não há como negar que "a manutenção da propriedade nas mãos de uma mesma fração de classe social restringe, em última instância, a livre expressão aos interesses diretos e indiretos dessa mesma classe” (MARINONI, 2015, p. 17).

Com este cenário, onde os meios midiáticos se caracterizam pela concentração e por interesses financeiros, fica claro que a opinião independente dentro desses setores é escassa. Esta situação, aliada à presença de patrocinadores, impedem a discussão de determinados assuntos, enquanto alavancam a abordagem de outros. Seguindo a lógica capitalista, o que não der audiência (lucro), ou não agradar aos patrocinadores (e aos acionistas), não deve ser veiculado. Isso é observado no discurso único jornalístico, "um sistema de reprodução de informações e pontos de vista que compartilha as mesmas fontes, agenda os mesmos temas e legitima os mesmos pontos de vista, no geral, com informações e declarações hegemonizadas pelas classes dominantes" (MARINONI, 2015, p. 17).

Além da concentração midiática, há ainda um outro agravante. As altas taxas de analfabetismo (absoluto ou funcional) ${ }^{3}$ fazem com que essa população tenha diminuída ainda mais sua forma de resistência à "realidade" mostrada pelos programas e telejornais. Levandose em consideração também que o analfabetismo está ligado a uma baixa renda (NAOE, 2012) - o que impossibilita o acesso aos canais de televisão por assinatura, bem como à internet - essa população é influenciada com maior intensidade, pois não possui a resistência da leitura e está restrita aos canais abertos, que estão sujeitos a cinco grandes conglomerados empresariais.

No aspecto que interessa a este trabalho - o tratamento midiático do tema da criminalidade e da segurança pública - a situação não é diferente. O discurso que prevalece é

\footnotetext{
3 "No Brasil, em 2019, havia 11 milhões de pessoas com 15 anos ou mais de idade analfabetas, o equivalente a uma taxa de analfabetismo de 6,6\%." No entanto, "nota-se que, no Brasil, o analfabetismo está diretamente associado à idade. Quanto mais velho o grupo populacional, maior a proporção de analfabetos. Em 2019, eram quase 6 milhões de analfabetos com 60 anos ou mais, o que equivale a uma taxa de analfabetismo de 18,0\% para esse grupo etário. Ao incluir, gradualmente, os grupos etários mais novos, observa-se queda no analfabetismo: para $11,1 \%$ entre as pessoas com 40 anos ou mais, 7,9\% entre aquelas com 25 anos ou mais e 6,6\% entre a população de 15 anos ou mais" (IBGE, 2019). Ou seja, o maior percentual de analfabetos está entre as pessoas mais velhas, justamente aquelas que passam mais tempo na frente da televisão, e, portanto, mais suscetíveis à influência midiática.

No caso do analfabetismo funcional, a situação é ainda mais calamitosa. Dados do de INAF (2018) indicam que em 2018 cerca de um terço da população brasileira (29\%) eram consideradas analfabetas funcionais.
} 
o da espetacularização da questão criminal e o reforço da pena de prisão. Assim, antes de destacar os aspectos centrais desse discurso, faz-se necessário observar o espaço que os principais canais televisivos brasileiros destinam aos programas que tratam ou se referem a este tema, para se ter maior percepção do impacto que esse discurso e a visão por ele veiculada possuem na sociedade.

\subsection{A PROGRAMAÇÃO}

Para demonstrar a relevância do impacto que a visão midiática sobre a criminalidade pode causar na população, o presente trabalho acompanhou, durante uma semana, a grade de programação semanal das seguintes redes televisivas: Globo, Record, Band, SBT e RedeTV!. Foi verificado o tempo que esses canais destinam a programas que, de forma direta ou tangencial, tocam no tema da criminalidade (principalmente a urbana) e da segurança pública: telejornais, programas policialescos ${ }^{4}$ e programas de variedades.

Selecionou-se como amostra a semana do dia 21 a 25 de junho de 2021. Embora seja uma única semana, ela revela a grade de programação que é costumeiramente veiculada pelos canais analisados ${ }^{5}$, e serve como ilustração para o que se pretende demonstrar. Por fim, a programação escolhida foi a do estado de São Paulo, pois é neste estado que se encontram as sedes da maior parte dos canais, é o estado que possui a maior concentração demográfica e também é o que mais concentra a produção audiovisual brasileira (MARINONI, 2015, p. 14). Assim, explicar-se-á brevemente um pouco sobre o conteúdo de cada tipo de programa analisado, e o porquê de sua importância.

Os programas policialescos, como a própria denominação demonstra, possuem como principal assunto a pauta criminal e da segurança pública, e, dentre os diversos artifícios que são utilizados para chamar a atenção do telespectador, se destaca o sensacionalismo. Tais

\footnotetext{
4 'Por 'policialescos' compreendem-se os programas de rádio e TV dedicados a narrar violências e criminalidades, sendo caracterizados pelo forte apelo popular. Diferentemente dos noticiosos em geral, que tratam de variados aspectos da vida social de modo relativamente equitativo, essas produções são focadas majoritariamente em temas vinculados a ocorrências de ordem policial, ainda que, eventualmente, insiram entre as narrativas um ou outro assunto estranho ao rol de fatos violentos, delituosos ou criminosos" (VARJÃO, 2015, p.12).

${ }^{5}$ A programação analisada pode ser conferida no anexo localizado ao final do artigo. Optou-se por analisar apenas os dias úteis - excluindo-se sábado e domingo - pois é durante o decorrer da semana que os canais televisivos dedicam a maior parte de sua programação às notícias e aos assuntos sociais, reservando os finais de semana, em maior medida, aos programas de entretenimento.

Além disso, urge ressaltar que, apesar de a amostra selecionar apenas uma semana do mês de junho do ano de 2021, a maioria dos programas que foram analisados são programas antigos, que já fazem parte do quadro permanente das emissoras, tais como os telejornais e os programas apresentados por personalidades específicas (como Fátima Bernardes, Sônia Abrão, José Luiz Datena etc.).
} 
programas já foram analisados em diversos trabalhos acadêmicos ${ }^{6}$, e o objetivo, neste momento, não é tanto o de se ocupar de seu conteúdo, mas sim o de apontar o tempo que eles ocupam na grade de programação dos principais canais televisivos do país.

Dessa forma, dentre os principais programas policialescos, se destacam: Brasil Urgente, apresentado pela Bandeirantes desde 2001, atualmente ocupa 3h20min da programação total da emissora; Cidade Alerta, apresentado desde meados de 1996 pela Rede Record, atualmente ocupa 3h10min; e Alerta Nacional, apresentado pela RedeTV!, atualmente ocupa 1h30min da grade da emissora. Este último foi inspirado no programa “Alerta Amazonas", apresentado por Sikêra Júnior, cujo bordão mais famoso é o "CPF cancelado", onde são comemoradas ações policiais que resultam na morte do suposto criminoso.

Já os telejornais, por sua vez, são os responsáveis por apresentar os principais acontecimentos do dia ou da semana para os telespectadores, e a questão criminal também é um tema sempre presente em suas notícias. De forma geral, eles utilizam tom neutro e tentam passar aparência de imparcialidade. Além disso, possuem modelos regionais, e os que se destinam às notícias de âmbito nacional são apresentados no "horário nobre", ou seja, no horário que possui maior audiência. Estes, apesar de não se utilizarem do sensacionalismo e não ocuparem tanto tempo da programação quanto os programas anteriormente citados, atingem um maior número de pessoas, e também apresentam as mesmas características estruturais ao noticiar fatos que envolvam crimes, como será abordado posteriormente.

Por fim, os programas de variedades se dividem entre diversos formatos e temas, e, normalmente, não possuem um assunto específico e estático (como nos telejornais ou programas policialescos). De forma geral, as temáticas abordadas se relacionam diretamente à sociedade à vida da população, mas também podem se ocupar da vida de celebridades, apresentações musicais ou até de culinária. NILO BATISTA (2002) pontua que, no Brasil, "cada vez mais, programas de variedades adotam formas judiciais" (p. 15), onde se referiu, especificamente, à maneira como são tratados alguns assuntos não necessariamente de cunho criminal.

No entanto, tais programas muitas vezes se ocupam, de forma intensa, de casos criminais, principalmente se tais casos atingem abrangência nacional. Para citar um exemplo, o "Encontro com Fátima Bernardes", veiculado pela Rede Globo, reiteradamente aborda assuntos relacionados à seara criminal em seus programas, onde muitas vezes são convidadas

${ }^{6}$ Cf. PATIAS (2005); RIBEIRO (2016), AMARAL e SWATEK (2020). 
vítimas e "especialistas", cuja função é a de comentar e explicar a questão debatida para os telespectadores. Isso pode ser vislumbrado no "debate" sobre o tráfico de drogas e de armas ${ }^{7}$, na entrevista de uma vítima de um sequestro e de um policial militar que nele atuou ${ }^{8}$, na “análise" sobre o perfil psicológico de assassinos passionais ${ }^{9}$, na "discussão" sobre crimes virtuais $^{10}$, na entrevista de uma celebridade vítima de roubo ${ }^{11}$, ou até mesmo sobre o até então não tipificado crime de "stalking"12.

Outros programas de variedades já chegaram a se envolver e interferir em casos criminais de grande repercussão nacional, como foi o caso do "A tarde é sua", da RedeTV!. No ano de 2008, a apresentadora Sônia Abrão entrevistou, ao vivo, o sequestrador de Eloá, enquanto ele mantinha a jovem e sua amiga reféns. Na ocasião, durante a entrevista (que durou em torno de 20 minutos), ela realizou perguntas de foro íntimo para o sequestrador, inclusive sobre sua infância, e interferiu na atuação policial. O mesmo programa também já protagonizou diversos outros casos de sensacionalismo, como na exibição reiterada e acompanhada de comentários de um vídeo em que era mostrado o assassinato de uma exdançarina de um grupo musical ${ }^{13}$.

Embora a questão criminal não seja o foco dos assuntos abordados nos programas de variedades, é certo que este é um tema que muitas vezes está presente em suas pautas, abrangendo desde crimes brutais e que atingiram repercussão nacional - onde se utiliza reiteradamente do sensacionalismo, o que os aproxima, de certa forma, dos programas policialescos - quanto de debates e conversas acerca da segurança pública e da criminalidade urbana. Em todos esses casos, a abordagem do assunto segue as mesmas características que serão detalhadas no próximo tópico, inclusive com o uso de "especialistas" para dar um tom de cientificidade e legitimidade para o que se afirma.

Após esses breves comentários, procede-se à exposição do tempo ocupado por esses programas nas grades de horários dos cinco canais analisados. Em todos eles, observou-se que mais de um terço de sua programação é dedicada a esses três tipos de conteúdo: telejornais,

\footnotetext{
${ }^{7}$ Cf. <https://globoplay.globo.com/v/5749447/>. Acesso em: 25 jun. 2021.

${ }^{8}$ Cf. <https://globoplay.globo.com/v/7859540/>; <https://globoplay.globo.com/v/7856585/>. Acesso em: 25 jun. 2021.

${ }^{9}$ Cf. <https://globoplay.globo.com/v/2458932/>. Acesso em: 25 jun. 2021.

${ }^{10}$ Cf. <https://globoplay.globo.com/v/5875016/>. Acesso em: 25 jun. 2021.

${ }^{11}$ Cf. <https://globoplay.globo.com/v/8939283/>. Acesso em: 25 jun. 2021.

${ }^{12} \mathrm{Cf}$. <https://globoplay.globo.com/v/2042705/>. Acesso em: 25 jun. 2021. O programa foi veiculado no ano de 2012, e o grande tema era o "atraso" da legislação penal brasileira em comparação à legislação estadunidense, onde esta prática já constituía crime. Em 2021, a perseguição obsessiva foi, enfim, tipificada, e passou integrar o Código Penal, com a inclusão do art. 147-A, sob a alcunha de "Perseguição".

$13 \mathrm{Cf}$. <https://www.redetv.uol.com.br/atardeesua/videos/ultimos-programas/video-pode-ser-motivo-da-morteda-ex-dancarina-da-gaiola-das-popozudas-5>. Acesso em: 25 jun. 2021.
} 
programas policialescos e programas de variedades - sendo que três deles dedicam mais da metade do tempo de sua programação a esse material. Em ordem decrescente, constatou-se que a Rede Record dedica aproximadamente 14h57min de sua programação a esse conteúdo; a Rede Globo, 12h50min; a Bandeirantes, 12h20min; o SBT, 11h16min; e a RedeTV!, 9h.

Portanto, além de a televisão estar presente em praticamente todos os domicílios brasileiros, suas grades de programação dedicam mais de um terço de seu tempo a programas que, direta ou indiretamente, tratam da questão criminal, demonstrando o alto peso que lhes é dado. Isso denota que o ponto de vista midiático sobre os problemas nacionais, principalmente os relacionados à violência, possuem grande presença na vida da população.

Condicionados principalmente pela concentração, os meios de comunicação e a imprensa brasileira como um todo - principalmente a televisiva, que atinge maior número de pessoas - são marcados pelo pensamento único e pela falta de pluralidade na informação. NILO BATISTA (2002) ilustrou bem esse fato ao se referir à discussão criminal na mídia, onde afirmou que "se na universidade um retribucionista e um preventista sistêmico podem desentender-se, na mídia complementam-se harmoniosamente" (p. 3-4).

No que tange à segurança pública e à criminalidade, não existem divergências estruturais no discurso midiático brasileiro. Tomando-se o conceito de ideologia proposto por LUDOVICO SILVA (2017), que a considera como "um sistema de valores e representações que tendem a preservar a estrutura social existente" (p. 60), pode-se afirmar que o discurso midiático brasileiro é um produtor de ideologia: a punição e a pena de prisão como única resposta, sem maiores discussões e problematizações, tal como observou BATISTA (2002).

O mesmo afirma CASARA (2017), para quem "os meios de comunicação de massa conseguem fixar sentidos e produzir ideologias, o que interfere na formação da opinião pública e na construção do imaginário social” (p. 108). E esta unicidade discursiva, produtora de ideologia, faz com que seja legitimada a atual onda punitiva brasileira. Utilizando-se do sensacionalismo, dos estereótipos, da ausência de visões diferentes sobre o tema e com a sempre presente reafirmação da punição, os oligopólios midiáticos ofuscam possíveis soluções para os problemas apresentados e reafirmam a punição como única resposta.

\section{O DISCURSO MIDIÁTICO}

O discurso midiático sobre a criminalidade possui um padrão bem específico: desprezo pela presunção de inocência, maniqueísmo, seletividade, vozes autorizadas e o reforço da ideia de punição para tudo o que envolva crimes. Para ZAFFARONI (2012), esse discurso segue a lógica de uma "criminologia midiática". Nas suas palavras, 
Poder-se ia dizer que, em paralelo às palavras da academia, há uma outra criminologia que atende a uma criação da realidade através da informação, subinformação e desinformação midiática, em convergência com preconceitos e crenças, que se baseia em uma etiologia criminal simplista, assentada em uma causalidade mágica. (...) O mágico é a ideia da causalidade especial, usada para canalizar a vingança contra determinados grupos humanos, o que (...) faz desses grupos humanos bodes expiatórios (p. 303).

Seu discurso é único e é de tal forma instrumentalizado que cria uma realidade paralela, com uma divisão explícita entre "pessoas de bem" e "criminosos", como será mostrado adiante. As notícias sobre a criminalidade são pautadas pelo que se convencionou chamar de "populismo penal", que pode ser conceituado como "o conjunto de técnicas especializadas para obtenção de consenso ou de apoio em torno da expansão de um poder, o punitivo" (GOMES, 2013, p. 53).

Para uma análise mais acurada sobre as formas de se veicular a criminalidade pelos diferentes tipos de telejornais, é preciso esclarecer que há distinção entre as notícias veiculadas por telejornais considerados "sérios" (ou de referência) e telejornais popularescos, de cunho sensacionalista. Aos primeiros é reservada maior credibilidade, devido à sua suposta objetividade e neutralidade na apresentação das notícias. Já o segundo tipo "extrai do fato, da notícia, a sua carga emotiva e apelativa e a enaltece: valoriza a emoção em detrimento da informação. Quase fabrica uma nova notícia que passa a se vender por si mesma" (PATIAS, 2005, p. 40).

No entanto, apesar dessas divergências formais entre os diferentes tipos de programa, este tópico objetiva demonstrar que, estruturalmente, o discurso é o mesmo: maniqueísta, seletivo, unívoco, desrespeitador da presunção de inocência e legitimadores da punição como solução.

\subsection{MANIQUEÍSMO}

A divisão simplista entre bem e mal, bom e ruim, é algo muito recorrente em séries e filmes da cultura pop. Nestes, geralmente, há a figura do herói, que encarna todas as qualidades positivas: bondade, honestidade, força, inteligência; e no seu contraponto está o vilão, que, por sua vez, encarna todas as qualidades negativas: maldade, crueldade, indiferença, sadismo etc. A criação deste vilão se dá também na vida real. Porém, não é nos filmes que ela acontece, e sim nos programas televisivos, principalmente os telejornais. Nestes, há a criação do inimigo, encarnado pelo acusado do momento, que, por sua vez, encontra sua antítese nos telespectadores. 
Esta divisão se dá com uma clara demarcação entre o criminoso - ou aquele que é mostrado pelo telejornal como tal - e a sociedade. Busca-se destacá-lo (e ao seu ato), diferenciando-o da coletividade. Enquanto esta última representa as vítimas e a reserva moral social, o primeiro é mostrado como inimigo, dissidente, cujo único objetivo é perturbar a tão bem quista paz social.

"O eles (...) incomodam, impedem de dormir com as portas e janelas abertas, perturbam as férias, ameaçam as crianças, sujam por todos os lados e por isso devem ser separados da sociedade, para deixar-nos viver tranquilos, sem medos (...). Nós somos limpos, puros, imaculados" (ZAFFARONI, 2012, p. 307, grifos do original).

Tal separação é mais explícita nos telejornais sensacionalistas: uma vez que nestes o apresentador possui maior liberdade de fala, seus comentários irão realizar a tarefa de demarcação. Em seu estudo sobre o programa Brasil Urgente, por exemplo, PATIAS (2005) registra que o apresentador “faz seus julgamentos: 'vagabundo', 'safado', 'sem-vergonha', "escória da sociedade", que são repetidos "com frequência, enquanto são exibidos os rostos dos acusados de roubo e outros crimes que o programa apresenta” (p. 48).

Já no telejornalismo de referência, essa demarcação é mais sutil, menos explícita. Para realizá-la, são utilizados diferentes recursos, tais como o modo como o fato é noticiado, as vozes autorizadas e as imagens mostradas. Em sua pesquisa sobre o discurso veiculado pelos telejornais de referência ${ }^{14}$ sobre a criminalidade, NATALINO (2007) preceitua que

\begin{abstract}
O exemplo mais comum dessa forma de construção do "nós" e do "eles" se encontra na rotulação estigmatizante dos criminosos, a quem não é dada voz, sendo sempre objeto e quase nunca sujeito do discurso. Como objeto do discurso, os criminosos são frequentemente referidos de forma pejorativa, implícita ou explicitamente, mediante, por exemplo, o uso de metáforas ou de adjetivações (p. 85).
\end{abstract}

As adjetivações negativas não precisam ser tão evidentes, como no telejornal sensacionalista; basta utilizar a palavra "traficantes", no lugar de "acusados", por exemplo, para que a divisão e demarcação seja feita. Isso é pontuado também por BATISTA (2002), que afirma que "na televisão, os âncoras são narradores participantes dos assuntos criminais (...) que se valem teatralmente da própria máscara para um jogo sutil de esgares e trejeitos indutores de aprovação ou reproche aos fatos e personagens noticiados” (p. 14).

Diante disso, a imagem que a mídia passa do delinquente é a de um inimigo social. E, como todo inimigo, “o direito lhe nega sua condição de pessoa. Ele só é considerado sob o aspecto de ente perigoso ou daninho" (ZAFFARONI, 2007, p. 18). Daí o tratamento rude e de desprezo com que os acusados são tratados por muitos repórteres e apresentadores de televisão. Uma pesquisa realizada com programas policialescos brasileiros, por exemplo,

${ }^{14}$ A pesquisa de NATALINO (2007) analisou os discursos do Jornal Nacional e do Jornal da Record. 
demonstrou que, com os acusados de crimes, "foi possível configurar pelo menos nove tipos de violações de direitos praticadas nas narrativas selecionadas e a infração a 19 dispositivos legais (12 brasileiros e sete multilaterais)" (VARJÃO, 2015).

Como mostrado, este modus operandi corresponde a uma criminologia midiática, que tem como papel justamente criar e manufaturar a realidade para a formação de um inimigo. Esta criminologia "cria a realidade de um mundo de pessoas decentes frente a uma massa de criminosos, identificada através de estereótipos que configuram um eles separado do resto da sociedade, por ser um conjunto de diferentes e maus" (ZAFFARONI, 2012, p. 307, grifo do original).

Com isso, os jornais e programas "jornalísticos" não transmitem "nenhum discurso capaz de provocar compreensão para além da divisão maniqueísta implícita no modelo narrativo" (NATALINO, 2007, p. 147). Sua figura é construída por meio de estereótipos e simplificações, e a única resposta possível para o problema é a prisão ou a eliminação física dos "criminosos".

O acusado de crimes é construído midiaticamente como um ser bestializado, maldoso e sem sentimentos. Tudo isso com o objetivo de gerar repulsa e medo por parte dos telespectadores, impossibilitando o sentimento de empatia e solidariedade para com os acusados - fator que é agravado pela ausência do ponto de vista desses sujeitos na mídia.

Sendo assim, tal divisão maniqueísta não poderia operar se esse inimigo criado não fosse muito bem construído. Desta forma, é necessário se criar um estereótipo, que se dá por meio de "uma imagem pública do delinquente com componentes de classe social, étnicos, etários, de gêneros e estéticos" (ZAFFARONI; BATISTA; ALAGIA; SLOKAR, 2006, p. 46).

A construção desse estereótipo é feita de muitas maneiras, e talvez a principal seja o constante enfoque dado a alguns crimes e a algumas áreas onde ele ocorre. No caso brasileiro, a constante estigmatização das periferias como antro do tráfico de drogas e violência cumpre dupla função: estigmatizar aquela região e seus moradores e criar a imagem do delinquente.

O tráfico de drogas, elevado a um dos maiores problemas sociais e incessantemente noticiado pela mídia, é o crime em que talvez esse estereótipo seja criado com maior sucesso. Os traficantes são mostrados como homens perigosos e fortemente armados, e sua imagem vinculada às favelas e periferias. Assim,

O estereótipo do bandido vai se consumando na figura de um jovem negro, funkeiro, morador de favela, próximo do tráfico de drogas, vestido com tênis, boné, cordões, portador de algum sinal de orgulho ou de poder e nenhum sinal de resignação ao desolador cenário de miséria e fome que o circunda (MALAGUTI, 2003, p. 36). 
Esse estereótipo foi verificado por NATALINO (2007) em sua pesquisa. Ao se referir à questão das drogas para jovens de classe média e para jovem das periferias, "há uma tendência do telejornalismo a um discurso criminal no caso do narcotráfico promovido pelas classes populares e um discurso medicalizador ou educativo sobre os usuários das classes abastadas" (p. 123), o mesmo que foi observado por MALAGUTI (2003), em sua pesquisa dos processos ligados à droga na $2^{\mathrm{a}}$ Vara de Menores do Rio de Janeiro.

Com a construção do estereótipo, todo e qualquer crime que os que nele se encaixam cometerem, será incessantemente mostrado pelos meios midiáticos, o que frequentemente tem como consequência a transformação desse acusado estereotipado em bode expiatório. Conforme definição do dicionário HOUAISS (2009), bode expiatório é a "pessoa ou coisa sobre que(m) se faz recair as culpas de outros ou qualquer problema”. É o que se pode observar: os ódios e indignações pelos problemas e mazelas sociais são voltados para esse inimigo, que pode ser considerado o responsável - mesmo que indireto - pelos problemas. Assim, a separação entre “eles” e "nós" faz com que sejam aceitas, com cada vez maior naturalidade, a restrição da liberdade e o advento de leis mais severas e punitivas. E, conforme LOLA ANIYAR DE CASTRO (1983),

Como o poder político, social, religioso e administrativo é reduzido a uma pequena minoria que controla os meios de informação e de comunicação, e os valores desta minoria são aceitos pela classe média (dirigentes, profissionais, clero, educadores e magistratura), é fácil entender o interesse em selecionar uma minoria de pessoas a serem sacrificadas em benefício da solidariedade de uma maioria (p. 131).

Para lidar com esse "outro", perigoso, violento, e que ameaça a segurança de todas as pessoas, a mídia fortalece a ideia da punição. Esta pode se dar por meio da incitação ao crime e à violência, mas a principal delas é a reafirmação da pena de prisão como solução para o conflito. De acordo com BATISTA (2002), esses veículos midiáticos "creem na pena como rito sagrado de solução de conflitos” (p. 3) - a única solução possível, para os mais diferentes tipos de problemas.

\subsection{SELETIVIDADE}

Os criminólogos e penalistas críticos a muito já demonstraram a seletividade estrutural do sistema de justiça criminal. Tendo em vista as limitações das agências executivas do sistema penal, é impossível inferir que elas abarquem a totalidade de atos delituosos que acontecem na sociedade. Com tal limitação, é inevitável que uma das facetas da seletividade 
seja que essas agências optem por abarcar aqueles delitos de mais fácil detecção, que em sua maioria são cometidos por aqueles que não possuem muitos recursos.

Dada essa seletividade estrutural do sistema, seria improvável que os telejornais e os meios midiáticos também não operassem por essa lógica. Porém, a razão utilizada pelos telejornais não é a utilizada pelas agências do sistema penal, a de menor esforço. Aqui entram outros fatores mais importantes, que influenciam na escolha daqueles acontecimentos que merecem um espaço no noticiário. Tendo em vista o infinito número de acontecimentos que ocorrem diariamente, e que teriam o condão de virar notícia, os meios midiáticos também devem operar pela seletividade. Ao selecionar as notícias, esses meios podem "tanto suprimir um tema na fixação da agenda, quanto priorizá-lo, construindo uma visão do entorno e, ainda, valores sociais, os quais serão absorvidos pela audiência" (ALMEIDA, 2013, p. 229-230).

Ao contrário do que deveria ser, o interesse público não é uma prioridade dos telejornais. E, tal qual o poder punitivo, a seleção não ocorre sem sentido. Ela é feita "de acordo com os apelos do clamor popular que, na realidade, é o clamor da criminologia midiática" (ZAFFARONI, 2012, p. 322). Com isso, o que é noticiado primeiro passa pelo crivo da maior audiência. Fatos chocantes, impactantes e inusitados tem preferência, por atraírem maior público ${ }^{15}$. Desta forma, quando há um crime que envolva atos bárbaros e brutais, estes são noticiados à exaustão.

No entanto, além de noticiarem crimes chamativos e incomuns (principalmente se envolverem extrema violência), o destaque recai principalmente nos crimes cometidos por aqueles estereotipados. Crimes como roubos, tráfico de drogas e sequestros - quando cometidos por essas pessoas - possuem lugar de destaque nesses jornais, que ligam sua atuação à sensação de insegurança social. Os meios midiáticos decidem, “com suas campanhas, a própria seleção criminalizante” (ZAFFARONI, 2012, p. 322).

$\mathrm{O}$ fato de se criar um estereótipo, e se noticiar com mais ênfase principalmente os crimes cometidos por essas pessoas, faz com que inconscientemente o telespectador associe os estereotipados com o cometimento de crimes. E essa associação se estende a todos aqueles identificados com o estereótipo, como preceitua ZAFFARONI (2012):

"Apesar de a enorme maioria de eles não ter cometido nenhum crime, são projetados
como potenciais delinquentes, sob a alegação que nunca saberemos quando passarão
da espreita à ação, mas assegurando que o farão; por isso, eles são maus e temíveis e

${ }^{15}$ Nos últimos anos, tem emergido no país uma nova forma de sensacionalismo e populismo penal. Trata-se da ênfase midiática nos crimes cometidos por políticos, especialmente aqueles vinculados à corrupção. Tal fenômeno não será analisado neste trabalho, por questões de delimitação do objeto. Para uma melhor discussão sobre este tema, cf. BALLOUTE (2020) e, especialmente, CASARA (2017) e GOMES e ALMEIDA (2013). 
ninguém deve assumir sua defesa nem discutir o que mostra a imagem, que é a única realidade midiática" (p. 310, grifo do original).

Com isso, tem-se os elementos para a criação de um pânico moral, onde alude-se à propaganda de Lei e Ordem e pede-se mais punição e rigor com os criminosos, que seriam os responsáveis pelos problemas vivenciados pela população. Este tipo de notícia, "devido ao seu alto grau de cooptação e rating, pode se revelar de curiosa utilidade na canalização e na indução de medos, predispondo o público ao punitivismo" (ALMEIDA, 2013, p. 231).

Não obstante, é importante destacar que cada estrato da população tem contato com a violência de forma diferenciada. Para os estratos da classe média, que estão menos expostos à violência e à criminalidade, a criminologia midiática cria uma realidade onde o perigo parece iminente, e o que se deve fazer é se proteger, custe o que custar, contra "eles", que estão do lado de fora e à espreita. Cria-se uma sensação de insegurança, que não corresponde à realidade.

Essa falsa sensação de insegurança foi notada por CASARA (2017), que dá o exemplo de as "pessoas que residem em áreas nobres no Rio de Janeiro, em que quase não ocorrem crimes, sentirem-se mais inseguras do que a população residente em áreas com alto índice de criminalidade"; segundo o autor, isso se dá pois essa última está "mais acostumada com a violência subjetiva e também com a violência estrutural, que é aquela inerente ao funcionamento normal das instituições na sociedade capitalista” (p. 155).

Nessa esteira, para a população com menor poder aquisitivo, o apelo é outro, tendo em vista que essas classes, por sua vulnerabilidade, estão mais expostas à violência. Com isso, enquanto para as classes médias os veículos de comunicação fabricam uma violência de que elas - em regra - não são vítimas, para as classes mais baixas a função desses veículos é "explicar" a violência que eles sofrem como fruto dos "inimigos" - ou seja, aqueles estereotipados, sobre quem recai a culpa de todos os males sociais.

Como não há divergência ou debate nesses veículos, "sua influência na construção da realidade social é fundamental e praticamente única", tendo em vista que "não há informações diretamente acessíveis ao indivíduo, como ocorre naquelas relacionadas ao sistema penal e seu funcionamento" (ALMEIDA, 2013, p. 231-232). Discussões mais amplas e profundas sobre os problemas sociais que a população vivencia não são debatidos. Tudo é reduzido ao binômio se há crime, deve haver punição, sem maiores reflexões sobre essas questões.

BATISTA (2002) percebeu o aspecto da seletividade ao descrever uma notícia em que repórteres da TV Globo filmaram uma espécie de pregão de venda de drogas em uma favela do Rio de Janeiro. Não havia nada de novo, nada que não fosse conhecido de antemão 
pelas pessoas, mas mesmo assim eles ganharam o prêmio Esso pela reportagem. Este exemplo demonstra claramente a seletividade, onde "o merecimento nem sempre provém do que se informa, mas também daquilo que se omite: a improvável reportagem sobre o desemprego e a miséria nas favelas" (p. 12).

Nesse sentido, há também de se notar que alguns crimes quase nunca são noticiados. É a indignação seletiva: apenas alguns crimes merecem ser divulgados. A mídia pauta as notícias e os crimes que devem ser mostrados e que devem gerar indignação. $O$ tráfico de drogas, assassinatos brutais, roubos e sequestros realizados contra as classes médias possuem preferência, independentemente da proporção em que ocorrem. NATALINO (2007) observa que essa seletividade é muito operante na escolha das notícias dos telejornais de referência:

\footnotetext{
A pesquisa demonstrou uma tendência forte de os telejornais apresentarem eventos ocorridos em metrópoles da região sudeste (...) [E], dentre os eventos relatados, as notícias envolvendo morte (assassinato, chacina e latrocínio) destacam-se como as mais presentes. Já as notícias de assalto foram exclusivamente relatadas em casos envolvendo a elite paulistana ou celebridades (p. 145).
}

Por outro lado, acidentes de trabalho, mortes no trânsito por embriaguez e os recorrentes assassinatos que ocorrem no campo não possuem - ou quase não possuem espaço proporcional nos noticiários que tratam sobre a criminalidade e a violência. Os crimes relacionados ao agronegócio também quase nunca aparecem. Em 2017, por exemplo, de acordo com a organização não governamental Global Witness, o Brasil bateu recorde de assassinatos de camponeses, líderes indígenas e ativistas ligados ao campo.

No mesmo ano também o número de assassinatos de quilombolas disparou (SOCIOAMBIENTAL). O número de pessoas submetidas ao trabalho escravo - onde quase 90\% dos casos se concentram no meio rural - também é alarmante (MELO, 2020). Notícias sobre o grande número de intoxicações dos trabalhadores rurais brasileiros por agrotóxicos também não possuem espaço (BOMBARDI, 2011). Quando comparados aos crimes que possuem preferência nos telejornais, estes crimes quase nunca aparecem. Não há motivo aparente para que este tipo de violência não seja noticiado, ao passo que outros crimes sem (ou com menor) lesão ao bem jurídico estejam diariamente presentes nos noticiários brasileiros, como o tráfico de drogas.

Embora não se tenha estudos que demonstrem relação de causa e efeito entre o que não é noticiado e quem são os patrocinadores e acionistas desses conglomerados, é curioso notar que a família Marinho (do grupo Globo), a família Saad (do grupo Bandeirantes), os donos da TV Vitoriosa (SBT Uberlândia, MG), e inúmeros outros donos de grupos midiáticos 
possuem íntima relação com o agronegócio, sendo proprietários de terra ou possuindo investimentos agropecuários (BANDEIRA; PASTI, 2018).

\subsection{AS VOZES}

Como demonstrado anteriormente, os crimes são apresentados seletivamente, de formas muitas vezes sensacionalista, de maneira a incitar o clamor por mais punição. No entanto, técnicas mais sofisticadas são utilizadas para dar maior credibilidade ao discurso. Uma dessas técnicas consiste em dar ou não dar voz a determinados agentes. Tanto no telejornalismo de referência, quanto no policialesco, existem vozes autorizadas e não autorizadas. Para essas últimas, resta o silêncio; quando muito, elas são utilizadas de forma distorcida, para legitimar o que se diz.

Como a solução apresentada para os crimes noticiados sempre se encontra na punição, essa crença em sua efetividade se constrói por diversos meios. Um deles é o recurso ao "especialista", que é quem legitima o que se afirma. "Tal legitimação implica a constante alavancagem de algumas crenças, e um silêncio sorridente sobre informações que a desmintam" (BATISTA, 2002, p. 3). Para tanto, os meios midiáticos se utilizam do apelo à autoridade, para dar credibilidade ao que se diz. Este apelo, que no discurso criminal pode ser de qualquer pessoa ligada à área - como um professor, um promotor, um delegado - somente é utilizado para corroborar o que foi afirmado (de forma explícita ou implícita) anteriormente.

NATALINO (2007), em sua dissertação de mestrado sobre o discurso da criminalidade violenta no telejornalismo de referência (aquele considerado "sério", que se contrapõe aos programas "policialescos"), afirma que existem três tipos de vozes autorizadas nesses telejornais,

\footnotetext{
e que elas correspondem com maior ou menor precisão à clássica distinção aristotélica entre os elementos retóricos do ethos, do logos e do pathos. Ao ethos, cuja base da validade argumentativa está na autoridade ou credibilidade da pessoa do falante e na justeza do seu código moral, associam-se aqueles cujo capital específico confunde-se com a credibilidade: os âncoras e os repórteres. Ao logos, cuja validade é dada pela razão, associam-se as vozes dos especialistas em geral. E ao pathos, cujo apelo argumentativo advém da capacidade de provocar empatia e afeto, são associadas as vozes das vítimas, de seus parentes e de seus amigos (p. 88).
}

Assim sendo, apenas essas três categorias possuem o direito à fala. A dos âncoras, por exemplo, é vital. Em toda notícia, mesmo que implicitamente, há a emissão de um juízo de valor. Enquanto nos jornais populares e programas policialescos esta opinião é explícita, muitas vezes com censuras morais e palavras ofensivas aos acusados, para o jornalismo 
"sério" a opinião vem implícita no tom mais solene, nas palavras utilizadas, na expressão facial.

A voz da vítima, por sua vez, é utilizada para comover o telespectador e fabricar a imagem do criminoso mau. A vítima e sua dor são utilizados deliberadamente com o intuito de gerar indignação nos telespectadores. O sofrimento das mesmas é maliciosamente ${ }^{16}$ explorado pelos meios midiáticos, que o utilizam como instrumento legitimador para se exigir mais punição. "Frente à dor das vítimas, o comunicador exige uma resposta imediata" (ZAFFARONI, 2012, p. 313). E essa resposta imediata tem um de seus reflexos na enorme quantidade de leis penais aprovadas precipitadamente, sem debate público anterior, e na cultura punitiva que se constrói a partir daí.

Há também a voz do "especialista" em sentido estrito. Este, geralmente alguém que atua diretamente com o sistema penal, é utilizado para dar um tom científico ao que se defende, mesmo que ele não seja um estudioso da área. Urge ressaltar que não é qualquer especialista que terá direito à voz, mas apenas aqueles que não divergirem do dogma da punição. Dessa maneira, como preceitua BATISTA (2002), o discurso midiático "selecionará os especialistas segundo suas opiniões coincidam ou dissintam daquelas crenças (punitivas)" (p. 8). Assim, "não há debate, não há atrito: todo e qualquer discurso legitimante da pena é bem aceito e imediatamente incorporado à massa argumentativa dos editoriais e das crônicas" (p. 4).

Aos acusados, o tratamento é diferente, dependendo do jornal em que a notícia está sendo veiculada. Nos programas sensacionalistas ou policialescos, a voz do acusado é utilizada parcialmente. Porém, há uma distorção nessa voz, conveniente à imagem que se pretende passar. Nesses programas e telejornais, dá-se "voz aos criminosos como forma de elevar a audiência e de auxiliar na construção da retórica estigmatizadora sobre aqueles" (NATALINO, 2007, p. 114). Ou seja, a fala dos acusados é utilizada para se construir uma imagem estigmatizada e estereotipada do mesmo, não correspondendo a um direito de resposta e nem servindo como contraditório.

\footnotetext{
${ }^{16}$ Optou-se pelo uso do adjetivo "maliciosamente" pois, de fato, a criminologia midiática explora a dor da vítima de forma fria e pragmática, sem se importar com as consequências daí advindas. ZAFFARONI (2012) explica como funciona o processo de exploração da dor da vítima, onde a criminologia midiática, depois de estimular seu sofrimento, oferendo um cenário para seu desenvolvimento, utiliza-se de sua imagem para produzir o sensacionalismo, interrompendo sua fase de construção do luto. Depois que essa vítima deixa de ser funcional, “a criminologia midiática se desvencilha dela e a ignora até silenciá-la por completo, sem se importar com o prejuízo psíquico que lhe provocou ao interromper sua elaboração do luto. Trata-a como uma coisa que se usa e, quando deixa de ser útil, se joga fora e se esquece” (p. 322, grifos do original).
} 
Já nos telejornais de referência, resta aos acusados o silêncio. Não há o direito ao contraditório - ou, quando há, o seu tempo é incomparavelmente inferior ao que foi utilizado para a acusação, e vem depois de que o “julgamento” já se realizou. Como esses veículos passam uma imagem de maior seriedade e objetividade, eles ficam impossibilitados de se utilizar dos mesmos recursos dos programas sensacionalistas, o que dificulta a veiculação de uma notícia policial que desperte o interesse e atenção dos telespectadores. Dessa forma, de acordo com NATALINO (2007),

Diante dessa dificuldade, são duas as principais estratégias utilizadas pelos telejornais de referência para a construção de sua narrativa: por um lado, o criminoso é construído como personagem sem voz, uma voz ausente; por outro, utilizam-se de outras vozes que não a dos jornalistas para emitir juízos de valor sobre esses personagens (p. 115).

Nas raras ocasiões em que se abre espaço para que os acusados possam falar, sua voz é de tal forma editada que ela mais serve para legitimar a acusação do que para sua defesa em si. Como dito anteriormente, a voz autorizada fica com os âncoras, repórteres, vítimas e "especialistas", ou seja, aqueles a quem o telejornal atribuíra a função de profundos conhecedores do assunto e merecedores de que sua opinião seja ouvida. Aos acusados, objetos da notícia, quase sempre o silêncio.

Desta forma, se constrói um discurso único, onde o que se passa é tido como verdade absoluta. Nenhuma voz dissidente aparece, nenhum discurso que contrarie a lógica punitivista tem espaço, nenhuma imagem que possa gerar empatia pelo acusado é mostrada. Há um profundo silêncio sobre tudo que contrarie o dogma da punição para aqueles considerados como criminosos.

\subsection{DESPREZO PELA PRESUNÇÃO DE INOCÊNCIA}

A presunção de inocência é um princípio e um direito constitucionalmente previsto no art. 5 $5^{\circ}$ LVII da CRFB/1988, sendo central para o processo penal brasileiro. Esse princípio basilar, fruto de uma conquista civilizatória, afirma que ninguém será considerado culpado até o trânsito em julgado da sentença penal condenatória. Isso quer dizer que a formação da culpa deve se dar no Judiciário, e, antes de uma decisão definitiva, aquele que é acusado é presumido/tido como se inocente fosse.

De acordo com LOPES JR. (2019), esse princípio atua em duas dimensões: uma interna ao processo, e outra exterior a ele. A primeira dimensão assevera que o ônus da prova é inteiramente da acusação, na dúvida o réu deve ser absolvido, e que as prisões cautelares devem ser bastante restritas. Já a dimensão exterior ao processo 
exige uma proteção contra a publicidade abusiva e a estigmatização (precoce) do réu. Significa dizer que a presunção de inocência (e também as garantias constitucionais da imagem, dignidade e privacidade) deve ser utilizada como verdadeiros limites democráticos à abusiva exploração midiática em torno do fato criminoso e do próprio processo judicial. O bizarro espetáculo montado pelo julgamento midiático deve ser coibido pela eficácia da presunção de inocência (p. 99).

Infelizmente, essa proteção não é observada na prática pela mídia brasileira. Os acusados, indiciados e réus são constantemente expostos ao público, por meio tanto da imagem quanto do nome completo. Há um verdadeiro desprezo pela presunção de inocência, por praticamente todos os meios midiáticos, como se essa garantia constitucional realmente não existisse.

Esse fato foi observado pelo Guia de Monitoramento das Violações de Direitos na televisão brasileira, pesquisa que realizou "o acompanhamento de 30 programas destinados a narrar ocorrências sobre violências e criminalidades, sendo 20 de TV e 10 de rádio, distribuídos em 10 cidades brasileiras" (VARJÃO, 2016, p. 11). Nessa pesquisa, foi constatado que em $88,4 \%$ dos programas analisados houve exposição indevida de pessoas, e em $82 \%$ houve desrespeito à presunção de inocência (idem, p. 24).

O mesmo observou PATIAS (2005) em sua pesquisa, onde, dentre os inúmeros direitos humanos desrespeitados pelo programa Brasil Urgente, está a “divulgação de imagens (...) de pessoas detidas pela polícia, sem a autorização das mesmas, imputação de autoria de crime a pessoa sem provas ou condenação transitada em julgado, entre outras” (p. 179).

A frequente exposição do rosto dos envolvidos, sem nenhum tipo de respeito por sua privacidade, é um reflexo direto da condição como essas pessoas são apresentadas: como inimigos, seres bestializados que não possuem nenhum direito, e que devem ser eliminados. Talvez isso contribua na explicação do porquê a maioria desses programas não sofrerem nenhum tipo de consequência por violar direitos e garantias fundamentais (VARJÃO, 2015).

\section{EFEITOS}

Pelo exposto, percebe-se que a mídia brasileira tende a desvirtuar a realidade dos fatos construindo uma narrativa com força de formar o imaginário de grande parcela da população. Esta, que enxerga nos monopólios midiáticos uma fonte de informação confiável (talvez por não ter acesso a outro ponto de vista, dada a concentração dos meios midiáticos), muitas vezes reproduz no dia-a-dia o discurso único que lhe é passado, seja em conversas informais, seja no apoio ou demanda de leis mais repressivas. 
Este último é o fator de maior impacto e preocupação, ocasionado por uma mídia sensacionalista, não comprometida com a verdade e nem ao menos com a garantia dos direitos humanos. Afinal, como destacam CALLEGARI e WERMUTH (2009):

\begin{abstract}
Em decorrência de interesses meramente mercadológicos, os meios de comunicação de massa promovem um falseamento dos dados da realidade social, gerando enorme alarde ao vender o "crime" como um rentável produto, respondendo às expectativas da audiência ao transformar casos absolutamente sui generis em paradigmas, aumentando, assim, o catálogo dos medos e, conseqüentemente e de forma simplista como convém a um discurso vendável, o clamor popular pelo recrudescimento da intervenção punitiva (p. 60).
\end{abstract}

Identifica-se que a estratégia da mídia nacional, ao tratar das "situações de crime", opera por uma simplificação estridente do fenômeno da criminalidade (principalmente a urbana), que, aliada à não reflexão e ao aprofundamento das causas e consequências dessa criminalidade mostrada, induz o público a crer na dicotomia entre "bom" e "mau". Por meio dos assíduos casos de crimes mostrados, se extrai que o lado "mau" é o dos agentes supostamente infratores, enquanto o lado "bom" é o daqueles que os perseguem e os colocam atrás das grades. E que, nessa guerra, vale tudo para punir os criminosos.

Outrossim, as imagens veiculadas são de fácil entendimento, não sendo necessário que o público opere grandes reflexões sobre o que assiste. A configuração maniqueísta é mostrada por meio de imagens "mastigadas", que não necessitam de maiores análises, além de muitas vezes sensacionalistas. Desta forma, as notícias são fabricadas para que sejam absorvidas e reproduzidas, o que impacta o discurso nas ruas, alimenta uma onda crescente de ódio ao "mal", e fortalece o estereótipo das classes sociais. Um exemplo disso pode ser verificado nos não tão episódicos linchamentos de furtadores, que inclusive já teve apoio público em um telejornal de grande audiência ${ }^{17}$.

Em se tratando de um espaço cuja liberdade deve mesmo ser permitida sem maiores travas, a mídia tem grande responsabilidade na veiculação de notícias que tem o poder de manufaturar a realidade. Não se fala aqui em fake news, mas sim em enfumaçar a realidade com filtros morais capazes de induzir o público a não notar por trás da fumaça. Por ser sutil,

\footnotetext{
17 Em 2014, um jovem acusado de praticar furtos na zona sul da cidade do Rio de Janeiro foi espancado e amarrado a um poste, com uma tranca de bicicleta, por três homens encapuzados. Durante a apresentação do jornal "SBT Brasil”, a então âncora do jornal Rachel Sheherazade fez um longo comentário sobre o caso, afirmando, dentre outras coisas, que tendo em vista a omissão do Estado em combater a criminalidade, era compreensível que a população assim procedesse, como forma de "legítima defesa coletiva" (sic). Este comentário gerou bastante polêmica e discussão nas redes sociais, e várias pessoas saíram tanto em defesa da jornalista, quanto reprovando sua atitude. Para maiores detalhes sobre o caso, ver: $<$ https://vejasp.abril.com.br/blog/pop/rachel-sheherazade-do-sbt-defende-grupo-que-amarrou-homem-nu-emposte-e-provoca-polemica/>. Acesso em: 25 jun. 2021.
} 
torna-se difícil distinguir entre uma notícia condizente com os fatos de mais uma cena romantizada com cortes estratégicos conforme o interesse midiático.

Ademais, como abordado anteriormente, o silêncio é outro fator muito importante na manufaturação dessa realidade. Tendo em vista que a internet ainda não atinge grande parte dos domicílios brasileiros (IBGE, 2018), a taxa de analfabetismo ainda continue alta, os meios midiáticos sejam oligopolizados, e a televisão atinja um percentual de 96,4\% de domicílios, aquilo que não passa na televisão, efetivamente não existiu. Assim, construir um bode expiatório que explique todas ou grande parte das mazelas sociais fica mais fácil.

O resultado de tudo isso é a divisão social, que fragiliza ainda mais aqueles que se encontram nas classes sociais menos favorecidas, sem a contrapartida do fortalecimento daqueles que teoricamente estariam no "topo" (no caso, a classe média, consumidora dos telejornais), que também vê cada vez mais sua liberdade diminuída - embora não o perceba com a crescente aprovação de legislações mais repressivas.

\subsection{OS REFLEXOS NO SISTEMA CARCERÁRIO}

Toda essa campanha midiática tem impacto significativo nos números referentes ao sistema carcerário brasileiro. No ano 2000, a população carcerária, que era de 232.755 pessoas, sofreu um aumento exponencial, e em 2015 o Brasil foi alçado ao posto de terceira maior população carcerária mundial (BARBON; TUROLLO JR., 2017). Atualmente o país conta com 759.518 presos em unidades prisionais, dos quais 228.976 (30\%) ainda não receberam condenação definitiva e 344.773 (49\%) estão no regime fechado (INFOPEN/20).

Essa população carcerária é majoritariamente identificada com um recorte muito específico da sociedade, os ditos "clientes preferenciais" da Criminologia Crítica. Isso é demonstrado pela mais recente coleta de dados (janeiro - junho de 2020) do perfil dos encarcerados no país pelo Departamento Penitenciário Nacional (DEPEN), onde $58 \%$ tem entre 18 e 34 anos, $95 \%$ são homens, e pretos e pardos somam 397.816 pessoas, cerca de $66 \%$ do número total que foi analisado pelo INFOPEN ${ }^{18}$.

Ademais, observa-se que quase um terço dos encarcerados $(32,39 \%)$ cumprem pena por crimes relacionados à Lei de Drogas, e 38,65\% por crimes contra o patrimônio, totalizando mais de $70 \%$ da população presa. Isso corrobora a afirmação de ZAFFARONI, BATISTA, ALAGIA e SLOKAR (2006), de que a "regra geral da criminalização secundária

\footnotetext{
${ }^{18}$ A população carcerária a que se refere esses dados é de 702.069 presos, pois neste levantamento não se incluem os presos que não estão sob tutela dos sistemas penitenciários os presos que estão sob monitoramento eletrônico.
} 
se traduz na seleção: a) por fatos burdos ou grosseiros (a obra tosca da criminalidade, cuja detecção é mais fácil)" (p. 46), e que é realizada por aqueles que possuem menos recursos.

Destarte, os dados demonstram que há um significativo contingente de homens, jovens, negros e pardos inseridos no sistema prisional, o que vai ao encontro do estereótipo divulgado midiaticamente. E o perfil dos encarcerados se repete ao longo dos anos, sofrendo variações apenas no que diz respeito ao número de presos. Infelizmente as tendências legislativas tendem a agravar esse quadro, com leis mais repressivas para o cometimento de crimes, e leis mais restritivas de direitos para aqueles que já se encontram encarcerados. Dada a seletividade estrutural do sistema penal, fica evidente quem serão os mais atingidos por ele: aqueles que, por sua condição, estão mais vulneráveis ao poder estatal - jovens, negros e pobres.

Esses dados não podem ser entendidos como obra do acaso. Embora não se possa atribuir à mídia toda a responsabilidade sobre o atual encarceramento brasileiro, é certo que ela contribui - e muito - para a sua legitimação. A falta de outro contraponto que não seja o punitivo, a exposição exacerbada e estereotipada de acusados de crimes, a espetacularização e superdimensionamento de determinados acontecimentos, enquanto se silencia sobre outros, favorece e fomenta o apoio popular por mais punição, que é consubstanciada na forma de leis penais mais rígidas e repressivas, e que recaem sobre os estratos sociais mais suscetíveis.

Portanto, o fator da influência midiática deve ser levado em consideração para pensar essa realidade. Afinal, no lugar de a preocupação dos congressistas ser a de legislar em matéria penal com a devida base sólida de garantias, eles são cada vez mais influenciados pelo clamor midiático por maior punição. E esta demanda, que também é social, por sua vez, é ocasionada pela sensação de insegurança e medo - catalisada e explorada pelos meios midiáticos - que evoca uma sensação de que a resposta para tudo seriam leis penais repressivas, pautadas na ideia de "tolerância zero".

Além disso, como demonstrado anteriormente, os meios midiáticos, em desrespeito total à Constituição, exibem exaltadamente os rostos de acusados de crimes, com os âncoras e repórteres muitas vezes realizando comentários desaprovadores. Há praticamente um préjulgamento, muitas vezes mesmo antes de iniciar o inquérito policial! Tudo isso relega à quase desaparição princípios como a presunção de inocência, a proporcionalidade, o devido processo legal, a efetiva proteção aos bens jurídicos relevantes e o direito penal de ultima ratio. Há uma verdadeira banalização e espetacularização das prisões (principalmente 
preventivas $)^{19}$, juntamente com os mandados de busca e apreensão, o que legitima o imenso contingente humano atualmente encarcerado.

\subsection{INFLUÊNCIA NA LEGISLAÇÃO}

O discurso midiático também exerce forte influência no recrudescimento normativo, que, por sua vez, é uma constante nacional desde a redemocratização. Ao longo de sua história legislativa, o país acumula diversos exemplos de leis penais editadas na onda punitiva instaurada pelos meios de comunicação de massa. São leis emergenciais, editadas com precipitação, sem maiores debates e muitas vezes sem rigor técnico, que possuem a única constante de restringir cada vez mais os direitos das pessoas. Para ilustrar tal fato, abaixo serão expostas algumas legislações penais que foram editadas sob forte pressão midiática.

O exemplo mais marcante talvez seja a alteração feita na Lei 8.072/90, a Lei dos Crimes Hediondos, para incluir o homicídio qualificado. Embora esta lei não se refira necessariamente à criminalidade urbana e àqueles estereotipados, ela ilustra bem a força que a mídia possui na produção legislativa brasileira. O contexto da alteração se deu em 1992, onde a atriz Daniella Perez foi assassinada brutalmente pelo ator que fazia seu par romântico em uma novela. Com o homicídio, houve grande repercussão midiática, inclusive internacional, causando grande comoção popular. Com isso, a mãe da atriz, a roteirista Glória Perez, encabeçou um abaixo assinado, que obteve mais de um milhão de assinaturas, para incluir o crime de homicídio qualificado nesta lei.

Assim, em 1994 foi publicada a Lei $n^{\circ}$ 8.930, que, além da inclusão do homicídio qualificado na Lei 8.072/90, também incluiu em seu rol outros crimes de cunho patrimonial e/ou que possuem como principais criminalizados pessoas das classes sociais mais baixas, tal como o latrocínio, a extorsão qualificada pela morte e a extorsão mediante sequestro na forma qualificada. Ou seja, junto com a reivindicação inicial da lei, de incluir o homicídio qualificado, houve também a inclusão de outros crimes anteriormente não previstos, o que aumentou ainda mais o recrudescimento penal.

A própria Lei dos Crimes Hediondos, que possuiu diversos dispositivos considerados inconstitucionais - como o cumprimento de pena integralmente em regime fechado - é mais uma lei que trata do problema do crime de forma simbólica, apenas atendendo a clamores

\footnotetext{
${ }^{19}$ De acordo com o INFOPEN 2020, os presos provisórios no Brasil atingem a impressionante marca de $29,81 \%$ da população prisional, quase um terço da população total analisada. Importante notar que esse número não corresponde ao número exato de presos provisórios, pois neste cálculo não foram considerados os presos que não estão sob a tutela dos Sistemas Penitenciários, nem os que estão sob monitoramento eletrônico.
} 
vingativos. "Usada sempre como uma resposta emergencial quando algum crime ganhava repercussão nacional, ela foi sendo constantemente alterada com a inclusão de inúmeros delitos" (PASTANA, 2019, p. 132). Atualmente, essa lei contém em seu bojo, também, outros delitos cuja criminalização secundária recai sobre os estratos sociais mais baixos, como o porte ilegal de arma de fogo uso proibido, o furto qualificado pelo uso de explosivo, e algumas hipóteses de roubo qualificado - trazidos pelo "Pacote Anticrime".

Mais recentemente, há o exemplo da Lei 13.654/2018, que nasce em um contexto onde, nos últimos anos, os veículos de comunicação começaram a divulgar, de forma mais reiterada, notícias sobre explosões ocorridas em caixas eletrônicos de cidades de todo o país, realizadas geralmente na parte da noite, para furtar as cédulas contidas em seu interior. Como resposta a essa nova demanda midiática, foram propostas diversos projetos de lei. Se destaca o Projeto de Lei do Senado (PLS) no 149/2015 que buscava dar uma resposta a essa situação. Inicialmente, o projeto tinha como objetivo apenas alterar o $\$ 3^{\circ}$ do art. 157 do Código Penal, aumentando a pena em dois terços para o roubo que fosse cometido com o uso de arma de fogo, ou em que houvesse destruição ou rompimento de obstáculo mediante o emprego de explosivo ou artefato análogo que causasse perigo comum.

Durante a tramitação do PLS, este foi emendado por uma senadora, que acrescentou mudanças aos artigos 155 e 157 do Código Penal, incluindo hipóteses dos crimes serem praticados com o uso de explosivos, ou serem realizados com o intuito de subtrair substâncias explosivas ou acessórios que possibilitassem a fabricação de explosivos. O projeto seguiu para a Câmara dos Deputados, se transformando no Projeto de Lei n 9.160/2017, onde, depois de encaminhado à Comissão de Segurança Pública e Combate ao Crime Organizado, recebeu apensos de outros projetos que tratavam da mesma temática.

Em um desses projetos que foram apensados ${ }^{20}$ - que previa alterações nas penas dos crimes previstos nos artigos 155, 156 e 157 que fossem praticados com explosivos - a justificativa utilizada pelo deputado foi que "toda semana os jornais de todo o país noticiam, quer furtos, quer roubos relacionados aos caixas eletrônicos e é preciso que o Estado garanta a segurança das pessoas quando utilizam essa tecnologia, que já faz parte do dia a dia de praticamente toda a população", o que demonstra a clara influência midiática na pauta legislativa.

Após todos os trâmites processuais, esse projeto de lei foi aprovado e deu origem à Lei 13.654, que foi promulgada no dia 23 de abril de 2018. Dentre as mudanças no Código

\footnotetext{
${ }^{20}$ No PL n ${ }^{\circ}$ 9.160/17, com os demais projetos apensados, consta a justificativa do deputado Severino Ninho
} sobre a necessidade de se realizar as alterações propostas, e foi se retirou a citação acima (BRASIL, 2017, p. 5). 
Penal que ela realizou, está a inclusão do $\S 4^{\circ}$-A ao art. 155 , que trata sobre o furto qualificado. De acordo com o novo dispositivo, se o delito for realizado com emprego de explosivo ou de artefato análogo que cause perigo comum, a pena, que antes era de dois a oito anos, passa a ser de quatro a dez anos. Tal mudança, além de elevar a pena abstrata, também influencia no início do regime de cumprimento da pena, pois retira a possibilidade de o condenado receber pena inferior a quatro anos.

Essa lei também alterou o art. 157 do Código Penal, acrescentando o inciso VI ao $\S 2^{\circ}$, que aumenta a pena de um terço até metade caso o roubo seja de substâncias explosivas ou de acessórios que possibilitem sua fabricação, montagem ou emprego. Além disso, inclui também o $\S 2^{\circ}$-A, que prevê o aumento de dois terços da pena caso o roubo seja cometido com arma de fogo, ou se houver destruição ou rompimento de obstáculo mediante o uso de explosivo ou artefato análogo que cause perigo comum. Por fim, caso a violência utilizada no roubo resultar em lesão corporal grave, a pena será de sete a dezoito anos de reclusão, e, se resultar em morte, de vinte a trinta anos $\left(\$ 3^{\circ}\right.$, I e II).

Outra lei extremamente simbólica, editada depois de ampla pressão midiática, foi a lei 12.347/12, a "Lei Carolina Dieckman". Instituiu-se o artigo 154-A no Código Penal, criminalizando o ato de invadir dispositivo informático alheio com o objetivo de obter, adulterar ou destruir dados neles contidos. Esta alteração legislativa se deu após a atriz Carolina Dieckman ter seu computador invadido por hackers, onde fotos íntimas da artista foram obtidas e divulgadas na internet após ela se recusar a lhes pagar a quantia de 10 mil reais. Após o incidente, o caso ganhou ampla repercussão nacional, e a pressão dos meios de comunicação foi forte para obter uma "resposta" do Estado. A resposta veio, em forma de mais uma tipificação.

Embora atualmente o caput e os parágrafos do art. 154-A tenham sido revogados pela Lei 14.155/2021, a lei que os instituiu ficou em vigor praticamente por oito anos, e, como consequência do seu caráter emergencial e imediatista, possuiu diversas atecnias jurídicas. Uma delas era a falta de precisão ao se delimitar o ato delituoso, pois apenas constituía crime invadir dispositivo informático alheio com a violação indevida de mecanismo de segurança. Ou seja, a lei nada dizia de uma invasão de dispositivos que não possuíssem mecanismo de segurança, deixando aberta uma enorme brecha. Isso sem falar da falta de efetividade do sistema penal para prevenir o cometimento de ilícitos cibernéticos. Nas palavras de PASTANA (2019), leis simbólicas, como essa em destaque, buscam apenas "respostas simples e imediatas para problemas que o Estado não vislumbra resolver” (p. 133). 
Na mesma esteira dos crimes cibernéticos, após massiva divulgação pelos meios midiáticos - nos últimos tempos - sobre as fraudes e crimes cometidos pelo meio digital, principalmente por meio dos aparelhos de telefone celular, em 2021 foi aprovada mais uma lei relacionada a esses ilícitos. Os principais exemplos utilizados pelos meios de comunicação para exigir uma resposta eram as fraudes perpetradas por golpistas - por meio do uso da internet e de telefones celulares - bem como os golpes atribuídos à presidiários. Com isso, a Lei 14.155/2015 incluiu alterações nos artigos 154, 155 e 171 do Código Penal, prevendo penas mais graves para os delitos cometidos de forma eletrônica ou pela internet.

Por fim, cabe assinalar que o "Pacote Anticrime", que teve grande parte de seu conteúdo aprovado e se tornou a Lei 13.964/2019, trouxe diversas mudanças na seara criminal $^{21}$, tais como o aumento de pena para diversos crimes, a restrição de direitos dos apenados, mudanças na Lei de Execução Penal e a inclusão de vários crimes na Lei 8.072/90. É interessante notar, na exposição de motivos, a constante referência que o então Ministro da Justiça do Governo Federal fez ao papel da imprensa e de suas notícias sobre a criminalidade, reputando-lhes credibilidade e confiabilidade na apuração de atos delituosos e na divulgação do aumento da criminalidade no país, o que justificaria o recrudescimento da legislação ${ }^{22}$.

Assim sendo, diante de todos esses exemplos, constata-se que a mídia exerce forte influência na produção legislativa penal no país. O Direito Penal é abordado pelos meios de comunicação de forma deturpada, sem debate e reflexão, o que faz com que a população passe a clamar junto com o noticiário a punição severa para aqueles que acreditam ser a fonte da criminalidade, o que culmina em leis penais simbólicas e sem efeitos. Assim, como CALLEGARI e WERMUTH (2009) prescrevem:

as reformas penais prescindem da doutrina penal, já não se faz mais necessário a
discussão das reformas antes de aprová-las, o importante é a repercussão midiática
que elas terão. Aqui aparece com toda a força o caráter simbólico do Direito Penal e
dos interessados nas repercussões e ganhos políticos que isso pode trazer. Volta-se
ao eficientismo e deixa-se de lado a efetividade. Na maioria das vezes, essas
reformas de cunho simbólico deixarão uma falsa impressão de segurança, porém,
sem qualquer comprovação efetiva de que de fato isso ocorreu (p. 74).

${ }^{21} \mathrm{O}$ "Pacote anticrime" trouxe diversas alterações ao Código Penal, e, dentre elas, se destacam: alteração do art. 75, elevando o tempo máximo de cumprimento de pena de 30 para 40 anos; inclusão do inc. VIII no crime de feminicídio, prevendo pena de doze a trinta anos caso o crime seja cometido com emprego de arma de fogo de uso restrito ou proibido; inclusão de dois parágrafos ao art. 141, prevendo a aplicação do dobro ou do triplo da pena caso o delito seja cometido mediante paga ou promessa de recompensa, ou se é cometido ou divulgado em quaisquer modalidades de redes sociais da rede mundial de computadores, respectivamente; supressão da saída temporária para o condenado por crime hediondo com resultado morte; aumento substancial do tempo necessário para a progressão de regime; inclusão na Lei 8.072/90 de modalidades do crime de roubo, furto qualificado pelo emprego de explosivo e o crime de posse ilegal de arma de fogo de uso proibido.

22 A exposição de motivos do então "Pacote Anticrime" pode ser acessada por este sítio: <http://www.planalto.gov.br/ccivil_03/Projetos/ExpMotiv/MJ/2019/14.htm>. Acesso em: 25 jun. 2021. 
Ponto chave para isso é a compreensão do cunho simbólico que se perpetua por meio da vinculação, pela mídia, da violência repressiva com o sucesso. Não é à toa que há uma sensação de fracasso por parte da população em geral quando uma prisão preventiva ou temporária ilegal é relaxada, ou mesmo quando algum apenado cumpre pena em regime diverso do fechado. Isso muitas vezes gera eco também entre os membros do Judiciário, que se sentem legitimados para cumprir os "anseios das ruas", e passam por cima de direitos e garantias constitucionais, bem como dos membros do Legislativo nacional.

Por fim, cabe ressaltar que esse mecanismo de fabricar leis punitivas se torna um ciclo vicioso. Embora existam "políticos que fazem isso por oportunismo ou por ideologia autoritária”, estes não são a maioria. De acordo com ZAFFARONI (2012):

\footnotetext{
"A verdade é que a maior parte dos políticos não tem ideia do problema e atua de acordo com a criminologia midiática porque não conhece outra e não sabe como defender-se de seu embate.

Os políticos confusos costumam acreditar que com concessões à criminologia midiática podem conter suas investidas, e quando percebem que isso não acontece, verificando até o efeito contrário, potencializador, ficam ainda mais confusos.

(...) Os políticos confusos não percebem que a criminologia midiática é substancialmente extorsiva e que frente a uma extorsão nunca se deve ceder, porque, cada vez mais, aquele que extorque exigirá mais e as concessões apenas fortalecerão seu método" (p. 233-234).
}

Dessa forma, cada vez que cedem à pressão e editam leis mais punitivas e autoritárias, mais cresce a demanda por parte da mídia. O que é feito nunca é suficiente; sempre se exige mais. E assim o ciclo se fecha em si mesmo, e o Estado Policial avança sobre o Estado de Direito. Se não houver uma quebra deste ciclo, não há saída democrática.

\section{CONSIDERAÇÕES FINAIS}

Diante do quadro apresentado, podemos dizer que a forma como a mídia brasileira veicula imagens da criminalidade urbana tem sido prejudicial para o avanço das mais básicas condições de dignidade humana, reforçando a desigualdade social já acentuada, além revelar uma realidade enfumaçada, recortada a partir do interesse daquele que veicula a imagem.

Levando-se em consideração o alto grau de inserção das televisões nos lares brasileiros, a oligopolização dos meios midiáticos, e que parcela significativa da população tende a ter na grande mídia uma fonte segura de informação, verifica-se que o cidadão fica refém das informações transmitidas. Como muitas vezes não possuem acesso a outros meios de informação, o discurso homogêneo midiático é passado como que se refletisse a realidade.

Agravado pelo excessivo tempo destinado a tratar do problema da criminalidade seja por telejornais, programas policialescos ou programas de variedades - em que há 
ausência de debate e opiniões divergentes, contribui-se para que esse discurso seja reproduzido acriticamente pelas pessoas. Com isso, imagens de repressão contra os estigmatizados, e a exposição e humilhação de acusados de crimes, acabam por ser absorvidas como corretas e devidas, tangenciando direitos humanos e fundamentais.

Por conseguinte, depreende-se que o discurso midiático brasileiro possui influência direta na (nem tão atual) onda punitivista vivenciada pelo país, onde o Poder Legislativo edita com cada vez mais velocidade e sem discernimento leis penais tipificando novas condutas, agravando penas, e restringindo mais direitos. É o efetivo uso do direito penal simbólico, onde, "na forma de uma deusa alada onipresente, vemos uma criminalização que resolve problemas, que influencia a alma dos seres humanos para que eles pratiquem certas ações e se abstenham de outras" (BATISTA, 2002, p. 4). Para cada novo problema que aparece, a única resposta estatal possível é a criminalização.

Assim, conclui-se que, sem enfrentar diretamente o oligopólio dos meios midiáticos e seu discurso único, sem aplicar a responsabilização dos mesmos pela violação de direitos fundamentais, e sem se efetivar o direito de resposta daqueles que são acusados, pouco ou nada pode se avançar na direção de um efetivo Estado de Direito. Enquanto não houver pluralidade de opiniões e diversidade de visões sobre um mesmo tema, com a suscitação de debates e exposição de ideias, o Estado Policial tende a avançar no país, e o status quo penitenciário tende a se manter e a se agravar.

\section{ANEXO - GRADE DE PROGRAMAÇÃO DOS CANAIS ANALISADOS}

\section{- GLOBO}

Conferir programação completa: <https://redeglobo.globo.com/sao-paulo/programacao/>. Acesso em: 21 jun. 2021.

Segunda-feira: Hora Um (04:00h-06:00h); Bom dia SP (06:00h-08:30h); Bom dia Brasil (08:30h-09:30h); Mais você (09:30h-10:45h); Encontro com Fátima Bernardes (10:45h12:00h); SP1 (12:00h-13:00h); Jornal Hoje (13:25h-15:00h); SP2 (19:10h-19:40h); Jornal Nacional (20:30h-21:30h); Jornal da Globo (00:40h-01:30h).

Terça-feira: Hora Um (04:00h-06:00h); Bom dia SP (06:00h-08:30h); Bom dia Brasil (08:30h-09:30h); Mais você (09:30h-10:45h); Encontro com Fátima Bernardes (10:45h- 
12:00h); SP1 (12:00h-13:00h); Jornal Hoje (13:25h-15:00h); SP2 (19:10h-19:40h); Jornal Nacional (20:30h-21:30h); Jornal da Globo (00:40h-01:30h).

Quarta-feira: Hora Um (04:00h-06:00h); Bom dia SP (06:00h-08:30h); Bom dia Brasil (08:30h-09:30h); Mais você (09:30h-10:45h); Encontro com Fátima Bernardes (10:45h12:00h); SP1 (12:00h-13:00h); Jornal Hoje (13:25h-15:00h); SP2 (19:15h-19:45h); Jornal Nacional (20:30h-21:40h); Jornal da Globo (00:25h-01:15h).

Quinta-feira: Hora Um (04:00h-06:00h); Bom dia SP (06:00h-08:30h); Bom dia Brasil (08:30h-09:30h); Mais você (09:30h-10:45h); Encontro com Fátima Bernardes (10:45h12:00h); SP1 (12:00h-13:00h); Jornal Hoje (13:25h-15:00h); SP2 (18:40h-19:10h); Jornal Nacional (20:00h-20:35h); Jornal da Globo (00:30h-01:10h).

Sexta-feira: Hora Um (04:00h-06:00h); Bom dia SP (06:00h-08:30h); Bom dia Brasil (08:30h-09:30h); Mais você (09:30h-10:45h); Encontro com Fátima Bernardes (10:45h12:00h); SP1 (12:00h-13:00h); Jornal Hoje (13:25h-15:00h); SP2 (19:10h-19:40h); Jornal Nacional (20:30h-21:30h); Jornal da Globo (00:15h-01:05h).

\section{- RECORD}

Conferir programação completa: <https://recordtv.r7.com/programacao/>. <http://comercial.recordtv.com.br/grade-de-programacao-semana/>. Acesso em: 21 jun. 2021.

Segunda-feira: Balanço Geral manhã (05:00h-08:30h); Fala Brasil (08:30h-10:00h); Hoje em dia (10:00h-11:45h); Balanço Geral SP (11:50h-15:15h); Cidade Alerta (16:45h-19:55h); Jornal da Record (19:55h-21:00h).

Terça-feira: Balanço Geral manhã (05:00h-08:30h); Fala Brasil (08:30h-10:00h); Hoje em dia (10:00h-11:45h); Balanço Geral SP (11:50h-15:15h); Cidade Alerta (16:45h-19:55h); Jornal da Record (19:55h-21:00h). 
Quarta-feira: Balanço Geral manhã (05:00h-08:30h); Fala Brasil (08:30h-10:00h); Hoje em dia (10:00h-11:45h); Balanço Geral SP (11:50h-15:15h); Cidade Alerta (16:45h-19:55h); Jornal da Record (19:55h-21:00h).

Quinta-feira: Balanço Geral manhã (05:00h-08:30h); Fala Brasil (08:30h-10:00h); Hoje em dia (10:00h-11:45h); Balanço Geral SP (11:50h-15:15h); Cidade Alerta (16:45h-19:55h); Jornal da Record (19:55h-21:00h); Repórter Record Investigação (22:45h-23:55h).

Sexta-feira: Balanço Geral manhã (05:00h-08:30h); Fala Brasil (08:30h-10:00h); Hoje em dia (10:00h-11:45h); Balanço Geral SP (11:50h-15:15h); Cidade Alerta (16:45h-19:55h); Jornal da Record (19:55h-21:00h).

- SBT

Conferir programação completa: <https://www.sbt.com.br/programacao>. Acesso em: 21 jun. 2021.

Segunda-feira: Primeiro Impacto (06:00h-11:00h); SBT Brasil (19:45h-20:30h); Programa do Ratinho (22:15h-23:30h); Operação Mesquita (01:45h-02:30h); Conexão Repórter (02:30h04:15h); SBT Brasil - Reprise (04:15h-06:00h).

Terça-feira: Primeiro Impacto (06:00h-11:00h); SBT Brasil (19:45h-20:30h); Programa do Ratinho (22:15h-23:15h); Operação Mesquita (02:00h-02:45h); Conexão Repórter (02:45h04:15h); SBT Brasil - Reprise (04:15h-06:00h).

Quarta-feira: Primeiro Impacto (06:00h-11:00h); SBT Brasil (19:45h-21:00h); Programa do Ratinho (23:00h-00:30h); Operação Mesquita (01:30h-02:15h); Conexão Conexão Repórter (02:15h-04:15h); SBT Brasil - Reprise (04:15h-06:00h).

Quinta-feira: Primeiro Impacto (06:00h-11:00h); SBT Brasil (19:45h-20:30h); Programa do Ratinho (22:15h-23:15h); Operação Mesquita (01:45h-02:30h); Conexão Repórter (02:30h04:15h); SBT Brasil - Reprise (04:15h-06:00h). 
Sexta-feira: Primeiro Impacto (06:00h-11:00h); SBT Brasil (19:45h-20:30h); Programa do Ratinho (22:15h-23:15h); Operação Mesquita (01:45h-02:30h); Conexão Repórter Conexão Repórter (02:30h-04:15h); SBT Brasil - Reprise (04:15h-06:00h).

\section{- BAND}

Conferir

programação

completa:

$<$ https://bandtv.band.uol.com.br/tv/programacao.asp?local=sp\&data=25/06/2021>. Acesso em: 21 jun. 2021.

Segunda-feira: $1^{\circ}$ Jornal (03:45h-06:00h); Bora SP (06:00h-07:30h); Bora Brasil (07:30h09:00h); Brasil Urgente (16:00h-19:20h); Jornal da Band (19:20h-20:25h); Band Notícias (22:00h-22:45h); Jornal da noite (00:30h-01:10h); + info (02:30h-02:40h); Jornal da Band Reprise (02:40h-03:45h).

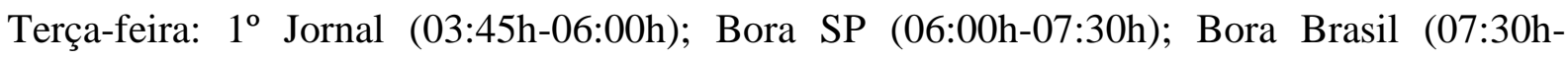
09:00h); Brasil Urgente (16:00h-19:20h); Jornal da Band (19:20h-20:25h); Band Notícias (22:00h-22:45h); Jornal da noite (23:45h-00:25h); + info (02:30h-02:40h); Jornal da Band Reprise (02:40h-03:45h).

Quarta-feira: $1^{\circ}$ Jornal (03:45h-06:00h); Bora SP (06:00h-07:30h); Bora Brasil (07:30h09:00h); Brasil Urgente (16:00h-19:20h); Jornal da Band (19:20h-20:25h); Band Notícias (22:00h-22:45h); Jornal da noite (00:00h-00:40h); + info (02:30h-02:40h); Jornal da Band Reprise (02:40h-03:45h).

Quinta-feira: $1^{\circ}$ Jornal (03:45h-06:00h); Bora SP (06:00h-07:30h); Bora Brasil (07:30h09:00h); Brasil Urgente (16:00h-19:20h); Jornal da Band (19:20h-20:25h); Band Notícias (22:00h-22:45h); Jornal da noite (00:25h-01:05h); + info (02:30h-02:40h); Jornal da Band Reprise (02:40h-03:45h).

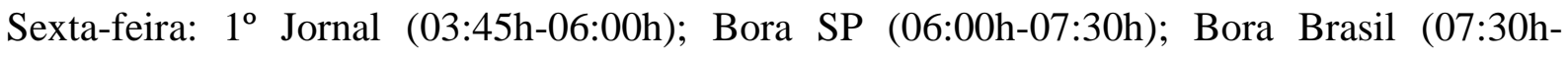
09:00h); Brasil Urgente (16:00h-19:20h); Jornal da Band (19:20h-20:25h); Band Notícias 
(21:10h-21:45h); Jornal da noite (00:00h-00:40h); + info (02:30h-02:40h); Jornal da Band Reprise (02:40h-03:45h).

\section{- REDETV!}

Conferir programação completa: 〈https://www.redetv.uol.com.br/programacao〉. Acesso em: 21 jun. 2021.

Segunda-feira: Vou te contar: com Cláudia Torres (10:30h-11:45h); Opinião no ar (11:45h12:55h); A tarde é sua: com Sônia Abrão (15:00h-17:00h); Alerta Nacional (18:00h-19:30h); RedeTV News (19:30h-20:00h); RedeTV News (20:03h-20:30h); Leitura dinâmica (00:30h$01: 15 h)$; Sensacional reprise (01:15h-02:15h).

Terça-feira: Vou te contar: com Cláudia Torres (10:30h-11:45h); Opinião no ar (11:45h13:00h); A tarde é sua: com Sônia Abrão (15:00h-17:00h); Alerta Nacional (18:00h-19:30h); RedeTV News (19:30h-20:00h); RedeTV News (20:03h-20:30h); Leitura dinâmica (00:30h01:15h); Vou te contar: com Cláudia Torres - reprise (01:15h-02:15h).

Quarta-feira: Vou te contar: com Cláudia Torres (10:30h-11:45h); Opinião no ar (11:45h13:00h); A tarde é sua: com Sônia Abrão (15:00h-17:00h); Alerta Nacional (18:00h-19:30h); RedeTV News (19:30h-20:00h); RedeTV News (20:03h-20:30h);

SuperPop (22:30h-00:00h); Leitura dinâmica (00:00h-00:45h).

Quinta-feira: Vou te contar: com Cláudia Torres (10:30h-11:45h); Opinião no ar (11:45h13:00h); A tarde é sua: com Sônia Abrão (15:00h-17:00h); Alerta Nacional (18:00h-19:30h); RedeTV News (19:30h-20:00h); RedeTV News (20:03h-20:30h); Sensacional (22:30h23:30h); Agora com Lacombe (23:30h-00:30h); Leitura dinâmica (00:30h-01:15h).

Sexta-feira: Vou te contar: com Cláudia Torres (10:30h-11:45h); Opinião no ar (11:45h13:00h); A tarde é sua: com Sônia Abrão (15:00h-17:00h); Alerta Nacional (18:00h-19:30h); RedeTV News (19:30h-20:00h); RedeTV News (20:03h-20:30h); Operação de risco - reprise (22:30h-23:30h); Leitura dinâmica (00:30h-01:15h); 


\section{REFERÊNCIAS BIBLIOGRÁFICAS}

ALMEIDA, Débora de Souza de. Parte II: Populismo midiático. In: GOMES, Luiz Flávio; ALMEIDA, Débora de Souza de. Populismo penal midiático: caso mensalão, mídia disruptiva e direito penal crítico. Coordenadores: Alice Bianchini, Ivan Luís Marques e Luís Flávio Gomes. São Paulo: Saraiva, 2013.

AMARAL, Augusto Jobim do; SWATEK, Tatiana das Neves. Criminologia midiática: um estudo sobre o programa "Cidade Alerta" (Rede Record de Televisão). Revista eletrônica do curso de Direito da UFSM, n. 1, v. 15, p. 1-28, 2020.

BALLOUTE, Samuel Rivetti Rocha. Corrupção, mídia e sistema penal: não há nada novo sob o Sol, Revista do CAAP, Belo Horizonte, n. 1, v. XXV, p. 1-24, $1^{\circ}$ semestre de 2020.

BARBON, Júlia; TUROLLO JR, Reynaldo. Brasil ultrapassa Rússia e agora tem a $3^{\mathrm{a}}$ maior população carcerária do mundo. Jornal Folha de São Paulo. São Paulo, 8 dez. 2017. Disponível em https://www1.folha.uol.com.br/cotidiano/2 017/12/1941685-brasil-ultrapassa-russia-eagora-tem-3-maior-populacao-carcerariado-mundo.shtml. Acesso em 25 jun. 2021.

BANDEIRA, Olivia e PASTI, André. Edição proprietários da mídia. Quem controla a notícia no Brasil. 16 de abril de 2018. Revista Le Monde Diplomatique Brasil. Disponível em $<$ https://diplomatique.org.br/quemcontrola-a-noticia-no-brasil/>. 25 jun. 2021.

BATISTA, Nilo. Mídia e sistema penal no capitalismo tardio. Discursos sediciosos: crime, direito e sociedade, Rio de Janeiro, ano 7 , n. 12 , p. $271-289,2^{\circ}$ semestre de 2002.
BECERRA, Martín; MASTRINI, Guillermo. La concentración infocomunicacional en América Latina 2000-2015: nuevos médios y tecnologías, menos actores. Bernal: Universidad Nacional de Quilmes, Observacom, 2017.

BOURDIEU, Pierre. Sobre a televisão. Tradução de Maria Lúcia Machado. Rio de Janeiro: Jorge Zahar Ed., 1997.

BRASIL. Constituição da República Federativa do Brasil de 1988. Brasília, DF: Presidência da República, [2016]. Disponível em: <http://www.planalto.gov.br/ccivil_03/con stituicao/constituicao.htm >. Acesso em: 25 jun. 2021.

BRASIL. Lei ${ }^{\circ} 8.072$, de 25 de julho de 1990. Dispõe sobre os crimes hediondos, nos termos do art. $5^{\circ}$, inciso XLIII, da Constituição Federal, e determina outras providências. Diário Oficial da União, 25 jul. 1990. Disponível em: <http://www.planalto.gov.br/ccivil_03/leis/ 18072.htm>. Acesso em: 25 jun. 2021.

BRASIL. Lei ${ }^{\circ} 8.930$, de 06 de setembro de 1994. Dá nova redação ao art. 10 da Lei no 8.072 , de 25 de julho de 1990, que dispõe sobre os crimes hediondos, nos termos do art. 5o, inciso XLIII, da Constituição Federal, e determina outras providências. Diário Oficial da União, 06 set. 1994. Disponível em: < http://www.planalto.gov.br/ccivil_03/leis/L 8930.htm\#art1>. Acesso em: 25 jun. 2021.

BRASIL. Lei $\mathrm{n}^{\circ} 12.737$, de 30 de novembro de 2012. Dispõe sobre a tipificação criminal de delitos informáticos; altera o Decreto-Lei $\mathrm{n}^{\circ}$ 2.848, de 7 de dezembro de 1940 - Código Penal; e dá outras providências. Diário Oficial da União, 30 nov. 2012. Disponível 
<http://www.planalto.gov.br/ccivil_03/_At o2011-2014/2012/Lei/L12737.htm\#art2>. Acesso em: 25 jun. 2021.

BRASIL. Projeto de lei $n^{\circ}$ 9.160, de 2017. Altera os arts. 155 e 157 do Decreto-Lei ${ }^{\circ}$ 2.848, de 7 dezembro de 1940 (Código Penal), para dispor sobre os crimes de furto qualificado e de roubo quando envolvam explosivos e do crime de roubo praticado com emprego de arma de fogo ou do qual resulte lesão corporal grave; tendo parecer da Comissão de Segurança Pública e Combate ao Crime Organizado, pela aprovação, com substitutivo do Projeto de Lei ${ }^{\circ} 5.989 / 2016$, apensado (relator: DEP. PASTOR EURICO). Câmara dos Deputados. Disponível em: $<$ https://www.camara.leg.br/proposicoesW eb/prop_mostrarintegra;jsessionid=4D9EF 8A899460BA3CEEA2011A79D797F.prop osicoesWebExterno1?codteor $=1641507 \&$ fi lename $=$ Avulso+-PL+9160/2017>. Acesso em: 25 jun. 2021.

BRASIL. Lei $\mathrm{n}^{\circ} 13.654$, de 23 de abril de 2018. Altera o Decreto-Lei ${ }^{\circ} 2.848$, de 7 dezembro de 1940 (Código Penal), para dispor sobre os crimes de furto qualificado e de roubo quando envolvam explosivos e do crime de roubo praticado com emprego de arma de fogo ou do qual resulte lesão corporal grave; e altera a Lei $\mathrm{n}^{\circ} 7.102$, de 20 de junho de 1983, para obrigar instituições que disponibilizem caixas eletrônicos a instalar equipamentos que inutilizem cédulas de moeda corrente. Diário Oficial da União, 23 abr. 2018. Disponível em: <http://www.planalto.gov.br/ccivil_03/_At o2015-2018/2018/Lei/L13654.htm\#art1>.

Acesso em: 25 jun. 2021.

BRASIL. Lei $\mathrm{n}^{\circ} 13.964$, de 24 de dezembro de 2019. Aperfeiçoa a legislação penal e processual penal. Diário Oficial da União, 24 dez. 2019. Disponível em: <http://www.planalto.gov.br/ccivil_03/_at o2019-2022/2019/lei/L13964.htm>.

Acesso em: 25 jun. 2021.
BRASIL. Lei $\mathrm{n}^{\circ} 14.155$, de 27 de maio de 2021. Altera o Decreto-Lei $\mathrm{n}^{\circ}$ 2.848, de 7 de dezembro de 1940 (Código Penal), para tornar mais graves os crimes de violação de dispositivo informático, furto $\mathrm{e}$ estelionato cometidos de forma eletrônica ou pela internet; e o Decreto-Lei ${ }^{\circ} 3.689$, de 3 de outubro de 1941 (Código de Processo Penal), para definir a competência em modalidades de estelionato. Diário Oficial da União, 27 maio 2021. Disponível em: < http://www.planalto.gov.br/ccivil_03/_Ato 2019-2022/2021/Lei/L14155.htm\#art1>. Acesso em: 25 jun. 2021.

BRASIL. Ministério da Justiça. Departamento Penitenciário Nacional. Levantamento nacional de informações penitenciárias. INFOPEN. Janeiro-junho de 2020. Brasília, 2020. Disponível em: $<$ https://www.gov.br/depen/pt-

br/sisdepen>. Acesso em: Acesso em: 25 jun. 2021.

CALLEGARI, André Luis; WERMUTH, Miquel Ângelo Dezordi. Deu no jornal: Notas sobre a contribuição da mídia para (ir)racionalidade da produção legislativa no bojo do processo de expansão do direito penal. Revista Liberdades, IBCCRIM, $\mathrm{n}^{\circ}$ 2, setembro - dezembro de 2009.

CASARA, Rubens R. R. O estado pósdemocrático: neo-obscurantismo e gestão dos indesejáveis. Rio de Janeiro: Civilização Brasileira, 2017.

CASTRO, Lola Aniyar de. Criminologia da reação social. Tradução de Ester Kosovski. Rio de Janeiro: Ed. Forense, 1983.

GLOBAL WITNESS. O ano com o maior número de mortes já registrado para defensores da terra e do meio ambiente. Julho, 2018. Disponível em $<$ https://www.globalwitness.org/en/pressreleases/o-ano-com-o-maiorn\%C3\%BAmero-de-mortes-j\%C3\%A1registrado-para-defensores-da-terra-e-do- 
meio-ambiente/>. Acesso em: 25 jun. 2021.

GOMES, Luiz Flávio; ALMEIDA, Débora de Souza de. Populismo penal midiático: caso mensalão, mídia disruptiva e direito penal crítico. Coordenadores: Alice Bianchini, Ivan Luís Marques e Luís Flávio Gomes. São Paulo: Saraiva, 2013.

GOMES, Luiz Flávio. Parte I: Teoria geral do populismo penal. In: GOMES, Luiz Flávio; ALMEIDA, Débora de Souza de. Populismo penal midiático: caso mensalão, mídia disruptiva e direito penal crítico. Coordenadores: Alice Bianchini, Ivan Luís Marques e Luís Flávio Gomes. São Paulo: Saraiva, 2013.

HOUAISS, Antônio; VILLAR, Mauro de Salles. Dicionário Houaiss da língua portuguesa. Rio de Janeiro: Objetiva, 2009.

INAF, Indicador de Alfabetismo Funcional. Relatório de resultados preliminares. Brasil, agosto, 2018. Disponível em: $<$ https://acaoeducativa.org.br/>. Acesso em: 25 jun. 2021.

INSTITUTO BRASILEIRO DE GEOGRAFIA E ESTATÍSTICA. Brasília, 2020. Acesso à Internet e à televisão e posse de telefone móvel celular para uso pessoal 2018. PNAD Contínua. Disponível em:

$<$ https://biblioteca.ibge.gov.br/visualizacao /livros/liv101705_informativo.pdf>.

Acesso em: 25 jun. 2021.

INSTITUTO BRASILEIRO DE GEOGRAFIA E ESTATÍSTICA. Brasília, 2020. Educação 2019. PNAD Contínua. Disponível em: <https://biblioteca.ibge.gov.br/visualizacao /livros/liv101736_informativo.pdf>. Acesso em: 25 jun. 2021.
INSTITUTO SOCIOAMBIENTAL. Violência contra quilombolas dispara em 2017. Outubro de 2017. Disponível em $<$ https://www.socioambiental.org/ptbr/noticias-socioambientais/violenciacontra-quilombolas-dispara-em2017?utm_medium=email\&utm_source $=$ tr ansactional\&utm_campaign $=$ manchetes $\% 4$ 0socioambiental.org>. Acesso em: 25 jun. 2021.

BATISTA, Vera Malaguti. Difíceis Ganhos Fáceis: Drogas e Juventude pobre no Rio de Janeiro. Rio de Janeiro: Revan, 2003.

LOPES JR., Aury. Direito Processual Penal. 16. ed. São Paulo: Saraiva Educação, 2019.

MARINONI, Bruno. Concentração dos meios de comunicação de massa e o desafi o da democratização da mídia no Brasil. Intervozes, 2015. Disponível em: $<$ https://intervozes.org.br/publicacoes/conc entracao-dos-meios-de-comunicacao-demassa-e-o-desafio-da-democratizacao-damidia-no-brasil/>. Acesso em: 25 jun. 2021.

MELO, Karine. Brasil teve mais de mil pessoas resgatadas do trabalho escravo de 2019. Agência Brasil online disponível em $<$ https://agenciabrasil.ebc.com.br/direitoshumanos/noticia/2020-01/brasil-teve-maisde-mil-pessoas-resgatadas-do-trabalhoescravo-em>. Acesso em: 25 jun. 2021. NAOE, Aline. Analfabetismo no Brasil evidencia desigualdades sociais históricas. Laboratório de Demografias e estudos populacionais. Universidade Federal de Juiz de Fora. Fevereiro de 2012. Disponível em: <https://www.ufjf.br/ladem/2012/02/24/an alfabetismo-no-brasil-evidenciadesigualdades-sociais-historicas/>. Acesso em: 25 jun. 2021. 
NATALINO, Marco Antônio Carvalho. O Discurso do Telejornalismo de Referência: criminalidade violenta e controle punitivo. São Paulo: Método, 2007. $283 \mathrm{p}$

PASTANA, Débora Regina. Política e punição na América Latina: uma análise comparativa acerca da consolidação do Estado Punitivo no Brasil e na Argentina. Rio de Janeiro: Revan, 2019. 351 p.

PATIAS, Jaime. O espetáculo da violência no telejornal sensacionalista: uma análise do "Brasil Urgente". Dissertação apresentada ao Programa de Pós-Graduação Stricto Sensu da Faculdade Cásper Líbero. São Paulo, 2005.

RIBEIRO, Fábio Ricardo dos Anjos. Telejornalismo policial e a legitimação do senso comum conservador em dois universos de recepção. Dissertação apresentada ao Programa de Pós Graduação em Ciências Sociais da Universidade Federal de Juiz de Fora. Juiz de Fora, 2016.

SILVA, Ludovico. A mais-valia ideológica. Florianópolis: Insular, 2017.
VARJÃO, Suzana. Violações de direitos na mídia brasileira: ferramenta prática para identificar violações de direitos no campo da comunicação de massa. (Guia de monitoramento de violações de direitos; v.1). Brasília, DF: ANDI, 2015. 80 p.

VARJÃO, Suzana. Violações de direitos na mídia brasileira: Pesquisa detecta quantidade significativa de violações de direitos e infrações a leis no campo da comunicação de massa. (Guia de monitoramento de violações de direitos; v.3). Brasília, DF: ANDI, 2016. 148 p.

ZAFFARONI, Eugenio Raúl; BATISTA, Nilo; ALAGIA, Alejandro; SLOKAR, Alejandro. Direito Penal Brasileiro: primeiro volume - Teoria Geral do Direito Penal. 3. ed. Rio de Janeiro, Revan, 2006. 660p.

ZAFFARONI, Eugenio Raúl. O inimigo no Direito Penal. Tradução de Sérgio Lamarão. 2. ed. Rio de Janeiro: Revan, 2007. 222 p.

ZAFFARONI, Eugenio Raul. A palavra dos mortos: Conferências de Criminologia Cautelar. Tradução de Cecília Perlingeiro, Gustavo de Souza Preussler, Lucimara Rabel e Maria Gabriela Viana Peixoto. São Paulo: Saraiva, 2012. 537p.

\section{REFLECTIONS ON BRAZILIAN MEDIA SPEECH AND THE LEGITIMATION OF PUNISHMENT}

Samuel Rivetti Rocha Balloute

How to cite this article: BALLOUTE, Samuel Rivetti Rocha. Reflexões sobre o discurso midiático brasileiro e a legitimação da punição Revista de Ciências do Estado. Belo Horizonte: v. 6, n. 1, e33004. ISSN: 2525-8036.

Abstract: This article aims to reflect on the approach that the Brazilian media gives to criminality (mainly urban), and how it contributes to the legitimacy of the current punitive state. The criminal issue is portrayed by the mass media in such a way that it produces distortions in reality and, consequently, influences the formation of opinions by the lay public, which trusts media information and often absorbs its message. His approach to the problem basically defaults to the reinforcement of stereotypes and the punitive ideal, with an absence of debates about different points of view. Thus, from the observation of the time that the five 
largest television channels allocate for programs that deal centrally or tangentially with the criminal issue, the impact that the media point of view causes on society is reflected on, seeking to demonstrate the correlation between the resurgence of criminal law, the increase in incarceration and the way the media approaches criminal news. The sampling procedure (to select and analyze the schedule of television channels) and the bibliographic review (to locate, investigate and interpret the problem defined in the Criminology scope) was used.

Keywords: Media; Criminal Law; Urban crime; Violence; Television. 